\title{
Altered gut microbiota and endocannabinoid system tone in obese and diabetic leptin-resistant mice: impact on apelin regulation in adipose tissue
}

\section{Lucie Geurts ${ }^{1}$, Vladimir Lazarevic ${ }^{2}$, Muriel Derrien ${ }^{3}$, Amandine Everard $^{1}$, Marie Van Roye $^{1}$, Claude Knauf $^{4}$ Philippe Valet ${ }^{4}$, Myriam Girard ${ }^{2}$, Giulio G. Muccioli ${ }^{5}$, Patrice François ${ }^{2}$, Willem M. de Vos ${ }^{3,6}$, Jacques Schrenzel ${ }^{2,7}$, Nathalie M. Delzenne ${ }^{1}$ and Patrice D. Cani ${ }^{3 *}$}

\author{
${ }^{1}$ Metabolism and Nutrition Research Group, Louvain Drug Research Institute, Université Catholique de Louvain, Brussels, Belgium \\ ${ }^{2}$ Genomic Research Lab, Geneva University Hospitals, Geneva, Switzerland \\ ${ }^{3}$ Laboratory of Microbiology, Wageningen University, Wageningen, Netherlands \\ ${ }^{4}$ INSERM U1048, Team 3, Institut des Maladies Métaboliques et Cardiovasculaires, Université Paul Sabatier, Université de Toulouse, Toulouse, France \\ ${ }^{5}$ Bioanalysis and Pharmacology of Bioactive Lipids Laboratory, Louvain Drug Research Institute, Université Catholique de Louvain, Brussels, Belgium \\ ${ }^{6}$ Department of Veterinary Biosciences, University of Helsinki, Helsinki, Finland \\ Laboratory of Bacteriology, Geneva University Hospitals, Geneva, Switzerland
}

\section{Edited by:}

Peter J. Turnbaugh, Harvard

University, USA

Reviewed by:

Alain Stintzi, Ottawa Institute of Systems Biology, Canada

Wendy Garrett, Harvard School of

Public Health, USA

*Correspondence:

Patrice D. Cani, Metabolism and Nutrition Research Group, Louvain Drug Research Institute, Université Catholique de Louvain, Avenue E. Mounier, 73 B1-73.11, B-1200

Brussels, Belgium.

e-mail: patrice.cani@uclouvain.be
Growing evidence supports the role of gut microbiota in the development of obesity, type 2 diabetes, and low-grade inflammation. The endocrine activity of adipose tissue has been found to contribute to the regulation of glucose homeostasis and low-grade inflammation. Among the key hormones produced by this tissue, apelin has been shown to regulate glucose homeostasis. Recently, it has been proposed that gut microbiota participate in adipose tissue metabolism via the endocannabinoid system (eCB) and gut microbiota-derived compounds, namely lipopolysaccharide (LPS). We have investigated gut microbiota composition in obese and diabetic leptin-resistant mice $(d b / d b)$ by combining pyrosequencing and phylogenetic microarray analysis of $16 \mathrm{~S}$ ribosomal RNA gene sequences. We observed a significant higher abundance of Firmicutes, Proteobacteria, and Fibrobacteres phyla in $d b / d b$ mice compared to lean mice. The abundance of 10 genera was significantly affected by the genotype. We identified the roles of the eCB and LPS in the regulation of apelinergic system tone (apelin and APJ mRNA expression) in genetic obese and diabetic mice. By using in vivo and in vitro models, we have demonstrated that both the eCB and low-grade inflammation differentially regulate apelin and APJ mRNA expression in adipose tissue. Finally, deep-gut microbiota profiling revealed that the gut microbial community of type 2 diabetic mice is significantly different from that of their lean counterparts. This indicates specific relationships between the gut microbiota and the regulation of the apelinergic system. However, the exact roles of specific bacteria in shaping the phenotype of $d b / d b$ mice remain to be determined.

Keywords: gut microbiota, type 2 diabetes, inflammation, LPS, endocannabinoid, apelin, APJ, metabolic endotoxemia

\section{INTRODUCTION}

Obesity and associated metabolic disorders (e.g., insulin resistance, type 2 diabetes, and cardiovascular diseases) are closely associated with a low-grade inflammatory state (Olefsky and Glass, 2010). Numerous studies have proposed that, in obese conditions, both the endocrine activity of adipose tissue and macrophage infiltration participate in the development of a lowgrade inflammatory tone (Olefsky and Glass, 2010). Compelling evidence supports the idea that adipokines participate in the regulation of glucose homeostasis and low-grade inflammation (Deng and Scherer, 2010; Federico et al., 2010). Among the recently discovered adipokines, apelin has been proposed as a novel key peptide involved in the regulation of several physiological functions. Apelin and APJ mRNA are widely expressed in mammals and exert functional effects in both the central nervous system and the periphery (Sorli et al., 2006). Apelin plays a key role in the cardiovascular system by acting on heart contractility, blood pressure, fluid homeostasis, vessel formation, and cell proliferation (Maenhaut and Van, 2011). Apelin serum levels are linked to the nutritional status and plasma insulin levels in both rodents and humans (Dray et al., 2008; Duparc et al., 2011a). Furthermore, apelin plasma concentrations are increased in obese subjects and in hyperinsulinemic obese mice compared to lean subjects (Dray et al., 2010). Interestingly, apelin has been shown to control glucose homeostasis by AMP-kinase- and nitric oxide (NO)-dependent mechanisms (Dray et al., 2008; Duparc et al., 2011b). Recently, it has been proposed that inflammation could participate in the production of apelin and the modulation of its receptor expression (Daviaud et al., 2006; Han et al., 2008a,b). Nevertheless, 
the mechanisms involved in the regulation of apelin and its specific $G$ protein-coupled receptor APJ have not been completely elucidated.

Growing evidence supports the role of gut microbiota in the development of obesity, type 2 diabetes, insulin resistance, and low-grade inflammation (Backhed et al., 2004; Ley et al., 2006; Turnbaugh et al., 2006; Cani et al., 2007a, 2008, 2009; Martinez et al., 2009; Vijay-Kumar et al., 2010). However, the composition of the gut microbiota and the exact role of the microorganisms present in the gut remain poorly defined. Nonetheless, advances in culture-independent methods for characterizing microbial diversity have helped to evaluate the functional contribution of this large collection of microbes in host metabolism (Martin et al., 2008; Turnbaugh et al., 2009). For instance, recent data suggest that changes in gut microbiota composition and gut barrier functions play a critical role in the development of obesity-associated inflammation (Brun et al., 2007; Cani et al., 2008, 2009; De La Serre et al., 2010). Accordingly, we have proposed that obesity-associated lowgrade inflammation and adipogenesis processes may be related to the gut microbiota by mechanisms involving the endocannabinoid system (eCB) and bacterially derived lipopolysaccharide (LPS; Cani et al., 2007a,b, 2008, 2009; De La Serre et al., 2010; Muccioli et al., 2010).

The eCB system is composed of endogenous lipids that activate specific $G$ protein-coupled receptors termed cannabinoid receptors 1 and $2\left(\mathrm{CB}_{1}\right.$ and $\left.\mathrm{CB}_{2}\right)$. Among these lipids, $N$-arachidonoylethanolamine (anandamide, AEA), and 2-arachidonoylglycerol (2-AG) are the most studied (Lambert and Muccioli, 2007). AEA and 2-AG are both widely present throughout the body, and their tissue levels are regulated by the balance between synthesis and inactivation. Briefly, Nacylphosphatidylethanolamines (NAPEs) are precursors for AEA through the activity of $N$-acylphosphatidylethanolamine-selective phospholipase-D (NAPE-PLD), whereas 2-AG can be synthesized mainly through diacylglycerol lipase (DAGL; Muccioli, 2010). Compelling strong evidence has shown that dysregulation of the tight control of endocannabinoid levels may result in pathological situations such as obesity and related metabolic syndromes or neurological disorders (Lambert and Muccioli, 2007). The main enzymes responsible for their degradation are fatty acid amide hydrolase (FAAH; Cravatt et al., 1996) and monoacylglycerol lipase (MGL; Dinh et al., 2002), respectively. Obesity and type 2 diabetes are associated with greater eCB system tone (altered expression of NAPE-PLD, $\mathrm{CB}_{1}$ mRNA, and higher eCB levels in plasma or adipose tissue; Muccioli et al., 2010). Moreover, LPS is known to stimulate eCB synthesis (Liu et al., 2003; Muccioli et al., 2010), and the gut microbiota participate in this complex regulation (Muccioli et al., 2010).

Although changes in the gut microbiota of obese mice $(o b / o b)$ or mice with high-fat diet-induced obesity were clearly demonstrated (Ley et al., 2005; Cani et al., 2007a,b; Turnbaugh et al., 2008, 2009; Hildebrandt et al., 2009), the exact composition of the gut microbiota of type 2 diabetic mice $(d b / d b)$ remains unknown. In light of these recent findings, we also decided to investigate the potential implication of these three key players (eCB, LPS, and the gut microbiota) in the regulation of apelin and APJ expression in adipose tissue. Therefore, we combined multiple molecular methods, including bar-coded pyrosequencing and phylogenetic microarray analysis of $16 \mathrm{~S}$ ribosomal RNA (rRNA) genes, to compare the gut microbial communities in genetic obese and diabetic mice with their lean littermates. The data presented herein demonstrated that apelin and APJ expression were down-regulated by the $\mathrm{eCB}$ in physiological conditions and were up-regulated by the bacteria-derived compound LPS in pathological situations. In addition, gut microbiota profiling revealed specific relationships between the gut microbiota and regulation of the apelinergic system and also potential novel bacterial targets that are essential to the host metabolism.

\section{MATERIALS AND METHODS MICE}

Six-week-old $d b / d b$ mice or lean littermates ( $n=6 /$ group; C57BL/ 6 background, Jackson-Laboratory, Bar Harbor, ME, USA) were housed in a controlled environment (12-h daylight cycle, lights-off at 6-pm) in groups of two mice/cage. Both groups of mice were given free access to similar control diet (A04, Villemoisson sur Orge, France) and tap water for 1 week.

All mouse experiments were approved by and performed in accordance with the guidelines of the local ethics committee. Housing conditions were specified by the Belgian Law of November 14, 1993, regarding the protection of laboratory animals (agreement number LA1230314).

\section{TISSUE SAMPLING}

Seven-week-old mice were anesthetized by intraperitoneal injection of $100 \mathrm{mg} / \mathrm{kg}$ ketamine and $10 \mathrm{mg} / \mathrm{kg}$ xylazine after a 5 -h fasting period. Blood samples were harvested for further analysis. Mice were sacrificed by cervical dislocation. Subcutaneous adipose deposits were dissected and immediately immersed in liquid nitrogen and stored at $-80^{\circ} \mathrm{C}$ for further analysis.

\section{PLASMA APELIN}

Apelin was measured using an Apelin EIA kit (Phoenix peptides) according to the manufacturer's instructions.

\section{MEASUREMENT OF ANANDAMIDE (AEA) TISSUE LEVELS.}

Tissues were homogenized in $\mathrm{CHCl}_{3}(10 \mathrm{ml})$, and a deuterated standard (d-AEA; $200 \mathrm{pmol}$ ) was added. Methanol $(5 \mathrm{ml})$ and $\mathrm{H}_{2} \mathrm{O}$ $(2.5 \mathrm{ml})$ were added, and lipids were then extracted by vigorous mixing. Following centrifugation, the organic layer was recovered, dried under a stream of $\mathrm{N}_{2}$ and purified by solid-phase extraction using silica, followed by elution with an EtOAc-Acetone (1:1) solution (Muccioli and Stella, 2008; Muccioli et al., 2010). The resulting lipid fraction was analyzed by HPLC-MS using an LTQ Orbitrap mass spectrometer (Thermo Fisher Scientific) coupled to an Accela HPLC system (Thermo Fisher Scientific). Analyte separation was achieved using a C-18 Supelguard pre-column and a Supelcosil LC-18 column $(3 \mu \mathrm{M}, 4 \times 150 \mathrm{~mm}$; Sigma-Aldrich). Mobile phases A and $\mathrm{B}$ were composed of $\mathrm{MeOH}-\mathrm{H}_{2} \mathrm{O}-$ acetic acid 75:25:0.1 (v/v/v) and MeOH-acetic acid 100:0.1 (v/v), respectively. The gradient $(0.5 \mathrm{ml} / \mathrm{min})$ was designed as follows: transition from $100 \%$ A to $100 \%$ B linearly over $15 \mathrm{~min}$, followed by $10 \mathrm{~min}$ at $100 \% \mathrm{~B}$ and subsequent re-equilibration at $100 \% \mathrm{~A}$. We performed MS analysis in the positive mode with an APCI ionization source. The capillary and APCI vaporizer temperatures were 
set at 250 and $400^{\circ} \mathrm{C}$, respectively. Anandamide was quantified by isotope dilution using its respective deuterated standard with identical retention. The calibration curves were generated as previously described (Muccioli and Stella, 2008), and the data were normalized by tissue sample weight.

\section{DNA ISOLATION FROM MOUSE CECAL SAMPLES}

The cecal contents of mice collected post mortem were stored at $-80^{\circ} \mathrm{C}$. Metagenomic DNA was extracted from the cecal contents (five $d b / d b$ and five lean) using a QIAamp DNA Stool Mini kit (Qiagen, Hilden, Germany) according to the manufacturer's instructions. Two cecal contents were not included in further gut microbiota analyses for technical reasons.

\section{S RRNA GENE AMPLIFICATION AND SEOUENCING}

For each sample, we amplified the V1-3 region of the bacterial 16S rRNA gene corresponding to Escherichia coli $16 \mathrm{~S}$ rRNA gene positions 28-514, excluding primer sequences. PCRs included $1 \mu \mathrm{l}$ of $50 \times$ diluted purified DNA, $0.5 \mu \mathrm{M}$ of forward B8fhomd ( $5^{\prime}$-gccttgccagccegctcag-ac-GAGTTTGATCMTGGCTCA G-3'), $0.05 \mu \mathrm{M}$ of forward B-8f-Bifido (5'-gccttgccagcccgctcagac-AGGGTTCGATTCTGGCTCAG- $3^{\prime}$ ), and $0.5 \mu \mathrm{M}$ of a barcoded reverse A-534RhomdDEGa primer ( $5^{\prime}$-gcctccctcgcgccatcagNNNNNNNN-at-CCGCGGCTGCTGGCAC-3') in $50 \mu \mathrm{l}$ of PrimeStar HS Premix (Takara). These primers included (i) the 454 Life Science 19-base adaptors A (lowercase underlined) or B (lowercase plain); (ii) an eight-base sample-specific barcode sequence (NNNNNNNN; designated 692-701 in Hamady et al. (2008); Table A1); (iii) the sequence of the broad-range $16 \mathrm{~S}$ forward or reverse primer (uppercase); and (iv) a dinucleotide sequence (lowercase italic) introduced between the $16 \mathrm{~S}$ primer and the barcode sequence designed to prevent pairing of different barcodes with rDNA targets.

PCRs were performed for 29 cycles at $98^{\circ} \mathrm{C}$ for $10 \mathrm{~s}, 56^{\circ} \mathrm{C}$ for $15 \mathrm{~s}$, and $72^{\circ} \mathrm{C}$ for $1 \mathrm{~min}$. One microliter of the sample was run on the Agilent 2100 Bioanalyzer using a DNA1000 lab chip to confirm the proper size. Two replicate reactions were pooled and cleaned using the QIAquick PCR purification kit (Qiagen). DNA concentration was assessed using a NanoDrop 1000 spectrophotometer. One hundred nanograms of each of the purified samples were pooled and sequenced on a Genome Sequencer FLX system (Roche).

Bar-coded 16S rDNA amplicons associated with several unrelated projects were included in the same sequencing run. A total of 39,548 reads, which had a quality score $<20$, corresponded to cecal samples from the 10 mice presented in this study.

\section{INFORMATIC ANALYSIS}

Sequences containing uncalled bases, incorrect primer sequences or runs of $\geq 10$ identical nucleotides were removed. Reads with the 16S rDNA forward oligonucleotide sequence CCGCGRCTGCTGGCGC, containing $\mathrm{G}$ instead of $\mathrm{A}$ at the penultimate position of the $3^{\prime}$ end, were likely due to a primer synthesis or sequencing artifact (Lazarevic et al., 2010) and were not removed from the dataset provided other quality criteria were met. After trimming primer sequences, reads $<200$ or $>290 \mathrm{nt}$ and those that incompletely covered the E. coli $16 \mathrm{~S}$ rRNA gene positions 288-514, determined using the RDP pyrosequencing tool Aligner (Cole et al., 2009), were discarded, leaving 31,577 sequences. Sequences were examined for potential chimeras using the MG-RAST server (Meyer et al., 2008).

Sequences were assigned to representative phylotypes at $97 \%$ identity (97\%-ID phylotypes) using CD-HIT (Huang et al., 2010). Distances between 97\%-ID phylotypes aligned by MUSCLE (Edgar, 2004) were calculated using FastTree (Price et al., 2009). Hierarchical clustering and principal coordinates analyses were performed using UniFrac (Lozupone et al., 2006). The taxonomic composition was assigned using the RDP Classifier (Wang et al., 2007) with a recommended $50 \%$ confidence cut-off. The sequences $(31,577$ reads) are publicly available at the MG-RAST repository (Meyer et al., 2008) under ID 4455129.

\section{MITCHIP: PCR PRIMERS AND CONDITIONS}

The Mouse Intestinal Tract Chip (MITChip) is a phylogenetic microarray consisting of 3,580 different oligonucleotides specific for the mouse intestinal microbiota (Derrien et al., in preparation). Both the design and analysis of the MITChip were performed as previously described for the human counterpart (Rajilic-Stojanovic et al., 2009). In short, $20 \mathrm{ng}$ of cecal DNA extract was used to amplify the $16 \mathrm{~S}$ rRNA genes with the primers T7prom-Bact-27-for $\left(5^{\prime}-\mathrm{T}\right.$ GAATTGTAATACGACTCACTATAGGGgtttgatcctggctcag- $\left.3^{\prime}\right)$ and Uni-1492-rev (5'-CGGCTACCTTGTTACGAC-3'). Subsequently, an in vitro transcription and labeling with $\mathrm{Cy} 3$ and $\mathrm{Cy} 5$ dyes was performed. Fragmentation of $\mathrm{Cy} 3 / \mathrm{Cy} 5$-labeled target mixes was followed by hybridization on the arrays at $62.5^{\circ} \mathrm{C}$ for $16 \mathrm{~h}$ in a rotation oven (Agilent Technologies, Amstelveen, The Netherlands). The slides were washed and dried before scanning. Signal intensity data were obtained from the microarray images using Agilent Feature Extraction software, version 9.1 ${ }^{1}$. Microarray data normalization and further analysis were performed using a set of R-based scripts ${ }^{2}$ in combination with a custom-designed relational database12, which operates under the MySQL database management system $^{3}$.

\section{RNA PREPARATION AND REAL-TIME OPCR ANALYSIS}

Total RNA was prepared from tissues using TriPure reagent (Roche). Quantitation and integrity analysis of total RNA was performed by running $1 \mu \mathrm{l}$ of each sample on an Agilent 2100 Bioanalyzer (Agilent RNA 6000 Nano Kit, Agilent). cDNA was prepared by reverse transcription of $1 \mu \mathrm{g}$ total RNA using a Reverse Transcription System kit (Promega, Leiden, The Netherlands). Real-time PCRs were performed with the StepOnePlus ${ }^{\mathrm{TM}}$ real-time PCR system and software (Applied Biosystems, Den Ijssel, The Netherlands) using Mesa Fast $\mathrm{qPCR}^{\mathrm{TM}}$ (Eurogentec, Seraing, Belgium) for detection according to the manufacturer's instructions. RPL-19 RNA was chosen as the housekeeping gene. Primer sequences for RPL-19, IL-1, F480, CD68, MCP-1, TNF- $\alpha$, Apelin, APJ, CB1, MGL, FAAH, and NAPE-PLD were previously described (Cani et al., 2008,

\footnotetext{
${ }^{1}$ http://www.agilent.com

${ }^{2}$ http://r-project.org

${ }^{3}$ http://www.mysql.com
} 
2009; Dray et al., 2008; Muccioli, 2010). The primer sequences for CD11c were F-ACG-TCA-GTA-CAA-GGA-GAT-GTT-GGA and R-ATC-CTA-TTG-CAG-AAT-GCT-TCT-TTA-CC. All samples were run in duplicate in a single 96-well reaction plate, and data were analyzed according to the $2^{-\Delta C T}$ method. The identity and purity of the amplified product was checked through analysis of the melting curve carried out at the end of amplification.

\section{ADIPOSE TISSUE EXPLANT CULTURES}

Subcutaneous adipose depots from 10 C57BL/6J (wild-type lean) mice were precisely dissected, and all visible vessels, particles, and conjunctive tissue were removed. The fat tissue was then cut with scissors into small pieces $\left(4 \mathrm{~mm}^{3}\right)$, pooled, and placed in Krebs buffer ( $\mathrm{pH} 7.4)$ containing $2 \%(\mathrm{w} / \mathrm{v})$ fatty acid-free BSA, penicillin $(100 \mathrm{IU} / \mathrm{ml})$, streptomycin $(100 \mu \mathrm{g} / \mathrm{ml})$, and amphotericin B $(2.5 \mu \mathrm{l} / \mathrm{ml}$; Invitrogen). A total of $250 \mathrm{mg}$ of adipose tissue was rinsed in phosphate-buffered saline and incubated in 100-mm Petri dishes containing $10 \mathrm{ml}$ MEM with Earle's salts (Invitrogen) supplemented with $0.5 \%$ fatty acid-free BSA, penicillin $(100 \mathrm{IU} / \mathrm{ml})$, streptomycin $(100 \mu \mathrm{g} / \mathrm{ml})$, and amphotericin $\mathrm{B}(2.5 \mu \mathrm{l} / \mathrm{ml}$; Invitrogen $)$. All conditions were repeated in four to five different dishes $(n=4-5)$. The dishes were cultured for $24 \mathrm{~h}$ at $37^{\circ} \mathrm{C}$ in a $5 \% \mathrm{CO}_{2}$ atmosphere. The basal concentration of glucose in fresh media was $5 \mathrm{mmol} / \mathrm{l}$, whereas the basal levels of cortisol and insulin were extremely low $(\sim 0.5 \mathrm{nmol} / 1$ and $3 \mathrm{pmol} / 1$, respectively). Different pharmacological agents were used in various combinations in accordance with the experimental protocols. LPS (E. coli 055:B5, $100 \mathrm{ng} / \mathrm{ml}$, Sigma) and HU-210 (100 nM, Tocris) were diluted in DMSO, which also served as a control. Cell viability did not change over the course of the experiment (data not shown). At the end of the experiment, the adipose material was rinsed in phosphate-buffered saline, collected, immediately frozen in liquid nitrogen, and stored at $-80^{\circ} \mathrm{C}$ until subsequent mRNA analysis.

\section{STATISTICAL ANALYSES}

The data are expressed as the mean \pm SEM. Differences between two groups were assessed using an unpaired, two-tailed Student's $t$-test. Statistical comparisons of bacterial communities were performed using a two-tailed Student's $t$-test, treating variances as equivalent. Correlations were analyzed using Pearson's correlation. Data were analyzed using GraphPad Prism version 5.00 for Windows (GraphPad Software, San Diego, CA, USA) and JMP 8.0.1 (SAS Campus Drive, Cary, NC, USA). The results were considered statistically significant at $P<0.05$.

\section{RESULTS}

16S RRNA ANALYSIS OF GUT BACTERIAL POPULATIONS IN OBESE AND DIABETIC MICE COMPARED TO LEAN MICE

Obese $(o b / o b)$ mice and diet-induced obese mice are characterized by an altered composition of the gut microbiota (Ley et al., 2005; Cani et al., 2007a,b; Turnbaugh et al., 2008, 2009). To date, the composition of the gut microbiota of leptin-resistant obese and type 2 diabetic $(d b / d b)$ mice has never been reported. The main differences between $o b / o b$ and $d b / d b$ mice are, first, in the leptin system, $o b / o b$ mice are leptin-deficient (they lack the $o b$ gene), whereas $d b / d b$ mice are leptin-resistant (the CNS has altered their "leptin receptors"), and, second, by phenotype, both mice are hyperphagic, severely obese and have developed fatty livers. However, $d b / d b$ mice become type 2 diabetic early after birth (a few weeks). This major difference between the two models confers to $d b / d b$ mice a clear advantage for investigating the role of the gut microbiota in this phenotype. The exact composition of the gut microbiota in this model of obesity and diabetes remains unknown. Therefore, we characterized the gut microbiota composition of obese and diabetic $d b / d b$ mice by two complementary approaches: pyrosequencing and phylogenetic microarray analysis of the 16S rRNA genes isolated from mouse cecal samples.

To explore bacterial diversity in cecal samples, we targeted the $16 \mathrm{~S}$ rDNA hypervariable region V3. A total of 31,577 sequence reads passed all quality control steps. We observed a significant increase of Proteobacteria $(32,227 \%)$ in $d b / d b$ mice compared to lean mice (Table 1). The abundance of 10 genera was significantly affected by the genotype (Table 1). Interestingly, the genera Odoribacter, Prevotella, and Rikenella were identified exclusively in the $d b / d b$ group, whereas Enterorhabdus was identified exclusively in lean mice (Table 1). Importantly, the abundance of the Tannerella genus was increased by approximately $17,112 \%$ in $d b / d b$ mice. The representatives of the class Deltaproteobacteria and the three genera of the phylum Bacteroidetes, all found exclusively in $d b / d b$ mice, are Gram-negative bacteria. Table A2 in Appendix shows the significant differences in 96 phylotypes (defined at 97\%-ID) enriched or depleted in $d b / d b$ mice. Furthermore, the results of the UniFrac analysis (Lozupone et al., 2006) clearly showed that $d b / d b$ cecal communities were more similar to each other than to the communities of the control lean mice (Figure 1A). Principal coordinate analysis (PCoA) of UniFrac-based pairwise comparisons of community structures revealed two clusters corresponding to the two dietary conditions (Figure 1B). Importantly, we found a marked positive relationship between the genus Oscillibacter and the expression of apelin and APJ ( $r=0.88, P=0.0006$, and $r=0.87, P=0.0011$, respectively). We also performed deep and global microbiota analysis using the MITChip, a high-throughput phylogenetic microarray designed after the human counterpart (Rajilic-Stojanovic et al., 2009), which was previously compared with 454 pyrosequencing (Claesson et al., 2009). The profiles of the cecal microbiota were obtained based on the hybridization to over 3,500 oligonucleotide probes and visualized the presence or absence of all targeted operational taxonomic units (OTUs). MITChip analysis revealed a clear separate clustering of the two treatment groups (Figures 2C,D) that shared $81.2( \pm 2.6) \%$ similarities (Pearson product-moment correlation coefficient). We observed a lower relative and absolute abundance of the phyla Bacteroidetes and Deferribacteres in $d b / d b$ mice compared to the lean group (Figures 2A,B,D), whereas we found a higher abundance of Firmicutes, Proteobacteria, and Fibrobacteres in $d b / d b$ mice compared to the lean group (Figures $2 A, \mathbf{B}, \mathbf{D}$ ). In accordance with the pyrosequencing analysis, both groups were found to cluster in a genotype-specific manner. In addition to specific changes observed in the pyrosequencing analyses, we found several previously unidentified modifications at a lower taxonomic level, 


\begin{tabular}{|c|c|c|c|c|c|}
\hline \multirow[t]{2}{*}{ Rank } & \multirow[t]{2}{*}{ RDP classification } & \multicolumn{2}{|c|}{$\begin{array}{l}\text { Abundance (percent } \\
\text { of total sequences)* }\end{array}$} & \multirow{2}{*}{$\begin{array}{l}\text { Change } \\
\text { in } d b / d b \\
\text { group** } \\
(\%)\end{array}$} & \multirow[t]{2}{*}{$\begin{array}{l}\boldsymbol{P} \\
\text { value*** }\end{array}$} \\
\hline & & Lean & $d b / d b$ & & \\
\hline Genus & Actinobacteria; Actinobacteria; Coriobacteriales; Coriobacteriaceae; Enterorhabdus & $0.019 \pm 0.008$ & 0 & LEAN [3] & 0.0449 \\
\hline Genus & Bacteroidetes; Bacteroidia; Bacteroidales; Porphyromonadaceae; Barnesiella & $0.464 \pm 0.148$ & $8.204 \pm 1.322$ & 1668 & 0.0004 \\
\hline Genus & Bacteroidetes; Bacteroidia; Bacteroidales; Porphyromonadaceae; Butyricimonas & $0.091 \pm 0.022$ & $0.006 \pm 0.006$ & -94 & 0.0061 \\
\hline Genus & Bacteroidetes; Bacteroidia; Bacteroidales; Porphyromonadaceae; Odoribacter & 0 & $0.150 \pm 0.040$ & DB [5] & 0.0053 \\
\hline Genus & Bacteroidetes; Bacteroidia; Bacteroidales; Porphyromonadaceae; Parabacteroides & $0.756 \pm 0.122$ & $0.235 \pm 0.070$ & -69 & 0.0060 \\
\hline Genus & Bacteroidetes; Bacteroidia; Bacteroidales; Porphyromonadaceae; Tannerella & $0.008 \pm 0.008$ & $1.346 \pm 0.328$ & 17112 & 0.0036 \\
\hline Family & Bacteroidetes; Bacteroidia; Bacteroidales; Prevotellaceae & 0 & $3.590 \pm 0.748$ & DB [5] & 0.0014 \\
\hline Genus & Bacteroidetes; Bacteroidia; Bacteroidales; Prevotellaceae; Prevotella & 0 & $2.443 \pm 0.463$ & DB [5] & 0.0008 \\
\hline Family & Bacteroidetes; Bacteroidia; Bacteroidales; Rikenellaceae & $4.262 \pm 0.802$ & $9.061 \pm 0.798$ & 113 & 0.0028 \\
\hline Genus & Bacteroidetes; Bacteroidia; Bacteroidales; Rikenellaceae; Alistipes & $4.262 \pm 0.802$ & $9.042 \pm 0.794$ & 112 & 0.0029 \\
\hline Genus & Bacteroidetes; Bacteroidia; Bacteroidales; Rikenellaceae; Rikenella & 0 & $0.019 \pm 0.008$ & DB [3] & 0.0409 \\
\hline Family & Firmicutes; Clostridia; Clostridiales; Ruminococcaceae & $7.259 \pm 1.231$ & $14.029 \pm 2.216$ & 93 & 0.0283 \\
\hline Genus & Firmicutes; Clostridia; Clostridiales; Ruminococcaceae; Oscillibacter & $5.831 \pm 0.858$ & $10.539 \pm 1.482$ & 81 & 0.0251 \\
\hline Phylum & Proteobacteria & $0.006 \pm 0.006$ & $2.036 \pm 0.570$ & 32227 & 0.0074 \\
\hline Class & Proteobacteria; Deltaproteobacteria & 0 & $1.227 \pm 0.292$ & DB [5] & 0.0030 \\
\hline
\end{tabular}

${ }^{*}$ Data are the mean $\pm S E$.

${ }^{*}$ Change in average taxa abundance in $\mathrm{db} / \mathrm{db}$ mice subset when compared to the lean mice subset. Only changes associated with a $P$ value $<0.05$ are given.

***P value was determined by a two-tailed Student's t-test with equal variance.

[Number] following LEAN or DB corresponds to the number of mice in the indicated subset in which the given phylotype was found.

especially the absolute and relative increase of Prevotella spp. (not shown).

\section{OBESE AND DIABETIC MICE EXHIBITED A HIGHER ENDOCANNABINOID SYSTEM TONE IN ADIPOSE TISSUE}

We have previously demonstrated that the gut microbiota contribute to the regulation of $\mathrm{eCB}$ system tone in adipose tissue in both physiological and pathological situations (Muccioli et al., 2010). In addition, obesity is characterized by higher eCB system tone in both humans and rodents (Engeli et al., 2005; Bluher et al., 2006; Matias et al., 2006; Cote et al., 2007; D'Eon et al., 2008; Starowicz et al., 2008; Izzo et al., 2009; Muccioli et al., 2010). Consistent with these findings, we discovered that $d b / d b$ mice, fed with a standard diet, exhibited an increased eCB system tone (AEA levels and mRNA expression). Anandamide (AEA; Devane et al., 1992) is an endogenous $C_{1}$ and $C B_{2}$ ligand. Here we found a significant increase in AEA levels (about 50\%) in adipose tissue (Figure 3A). In accordance with this result, NAPE-PLD and $\mathrm{CB}_{1}$ mRNA expression were significantly increased, whereas mRNA expression for the AEA-degrading enzyme FAAH was reduced (Figures 3B,C,D). Note that expression of monoacylglycerol lipase (MGL), the main enzyme that degrades endocannabinoid 2-arachidonoylglycerol (2-AG), tended to be higher in the adipose tissue of $d b / d b$ mice (Figure 3E), which is consistent with the reduced 2-AG levels observed in adipose tissue (Figure 3F). Altogether, these data demonstrate for the first time that $d b / d b$ mice display an altered eCB system tone in adipose tissue, and more specifically, they display increased signaling for the endocannabinoid AEA.

\section{INCREASED APELIN AND APJ EXPRESSION IN THE ADIPOSE TISSUE OF OBESE AND DIABETIC MICE}

Recent evidence suggests that, in pathophysiological conditions (obesity and type 2 diabetes), the peripheral apelinergic system seems to be deregulated (Dray et al., 2008, 2010; Duparc et al., 2011a). To date, the mechanisms of regulation of apelin and APJ expression in the adipose tissue of obese and diabetic mice are not fully understood. Therefore, we investigated apelinergic system tone in this model and found that apelin and APJ mRNA levels were significantly increased by two- and threefold, respectively, in the adipose tissue of $d b / d b$ mice compared to lean littermates (Figures 4A,B). Plasma apelin was increased by approximately $30 \%$, but did not reach significance $(d b / d b: 7.1 \pm 1$, lean: $5.8 \pm 0.8 \mathrm{pg} / \mathrm{ml})$.

Interestingly, we found several positive and negative correlations between the abundance of specific bacteria and apelin/APJ expression, suggesting a potential relationship between specific gut bacteria and the regulation of the apelinergic system (Table 2).

\section{INCREASED LOW-GRADE INFLAMMATION IN THE ADIPOSE TISSUE OF DB/DB MICE}

We have previously demonstrated that the higher eCB system tone observed in the adipose tissue of obese and diabetic mice was directly dependent on low-grade inflammatory tone (Muccioli et al., 2010). In addition, $d b / d b$ mice are considered a widely used model to investigate the metabolic features associated with obesity and type 2 diabetes. These mice are characterized by a low-grade inflammatory tone with higher plasma LPS levels 


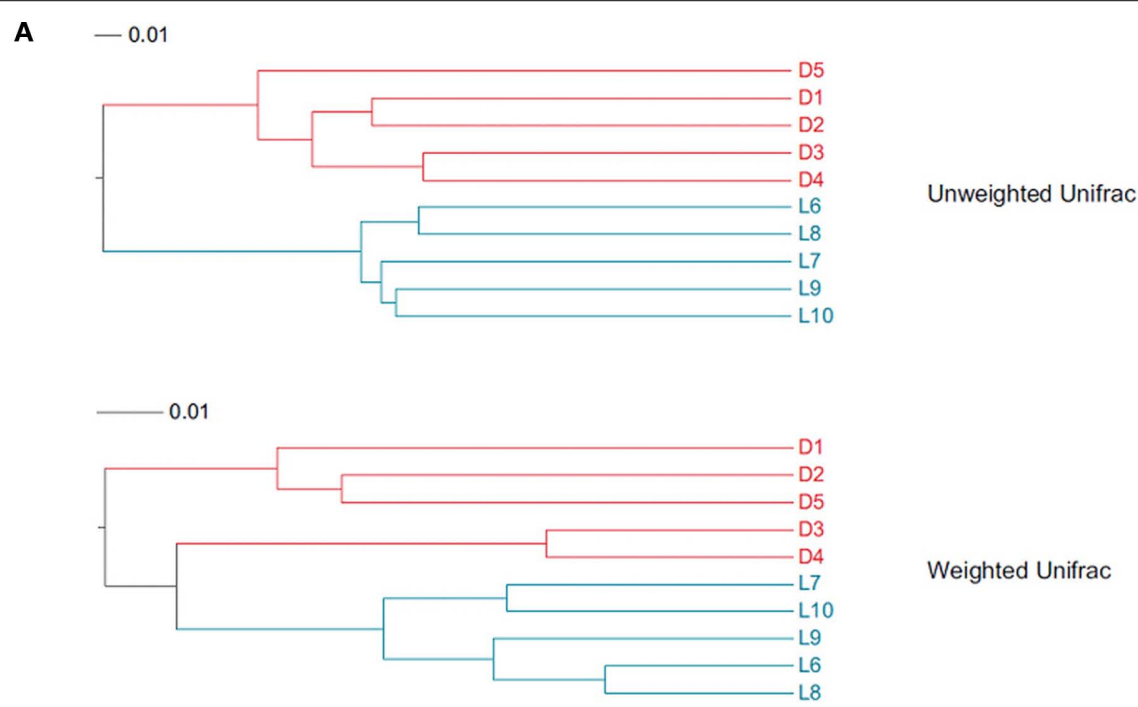

B

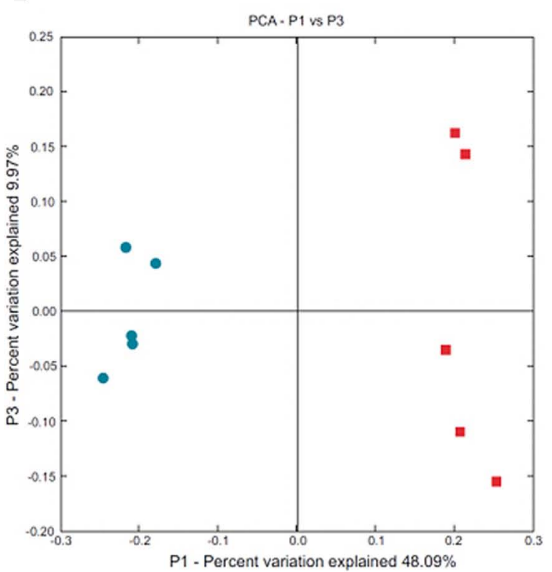

Unweighted UniFrac

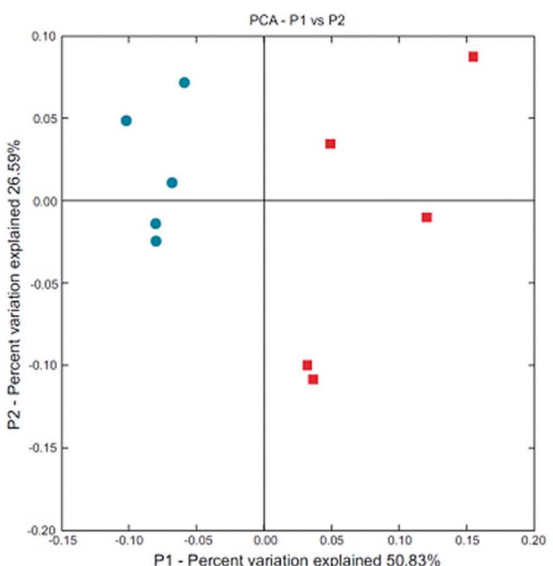

Weighted UniFrac
FIGURE 1 | Analysis of gut bacterial communities by $16 \mathrm{~S}$ rRNA pyrosequencing from obese diabetic mice or lean mice. (A) Clustering of mouse cecal microbial communities in the two tested groups based on unweighted UniFrac analysis and 97\%-ID phylotypes. Red indicates the diabetic mice $(d b / d b)$, and blue indicates the lean mice. Branch length represents the distance between environments in UniFrac units, indicated by the scale bar ( $n=5 /$ group). (B) PCoA analysis based on unweighted (presence/absence) UniFrac analysis and 97\%-ID phylotypes. Each symbol (filled circle or filled square) representing a single sample is colored according to dietary conditions: red corresponds to $d b / d b$, and blue corresponds to lean ( $n=5 /$ group). and significantly higher plasma levels of IL-1 $\beta$, IL-6, TNF- $\alpha$, and INF- $\gamma$ (Brun et al., 2007). Moreover, the assessment of adipose tissue inflammation revealed an increased number of crownlike structures corresponding to proinflammatory macrophages that are F4/80 and CD11c positive (Mihara et al., 2010; Hellmann et al., 2011). Consistent with numerous previous reports investigating meta-inflammation in this model, we found a significant increase in both inflammation and macrophage infiltration markers in our $d b / d b$ mice. The markers investigated in this study (IL-1, Monocyte Chemoattractant Protein-1 (MCP-1), F4/80, CD11c, and CD68 mRNA expression) were all significantly increased by 50 to $400 \%$ in $d b / d b$ mice compared to lean mice (Figures 5A-E).

\section{BOTH THE ECB SYSTEM AND LOW-GRADE INFLAMMATION PARTICIPATE IN THE REGULATION OF ADIPOSE TISSUE APELIN AND APJ EXPRESSION}

Understanding the molecular mechanisms responsible for the altered apelinergic system is essential to find putative novel targets for modulating adipose tissue metabolism. We have previously shown that both the low-grade inflammatory tone and the higher eCB system tone observed in obesity and related disorders could be linked to gut microbiota composition (Cani et al., 2009; Muccioli et al., 2010; Cani and Delzenne, 2011). More importantly, it has been previously demonstrated that inflammation regulates both apelin and APJ mRNA expression (Daviaud et al., 2006; MelgarLesmes et al., 2011). In addition, our in vivo experiments and 


\section{A}

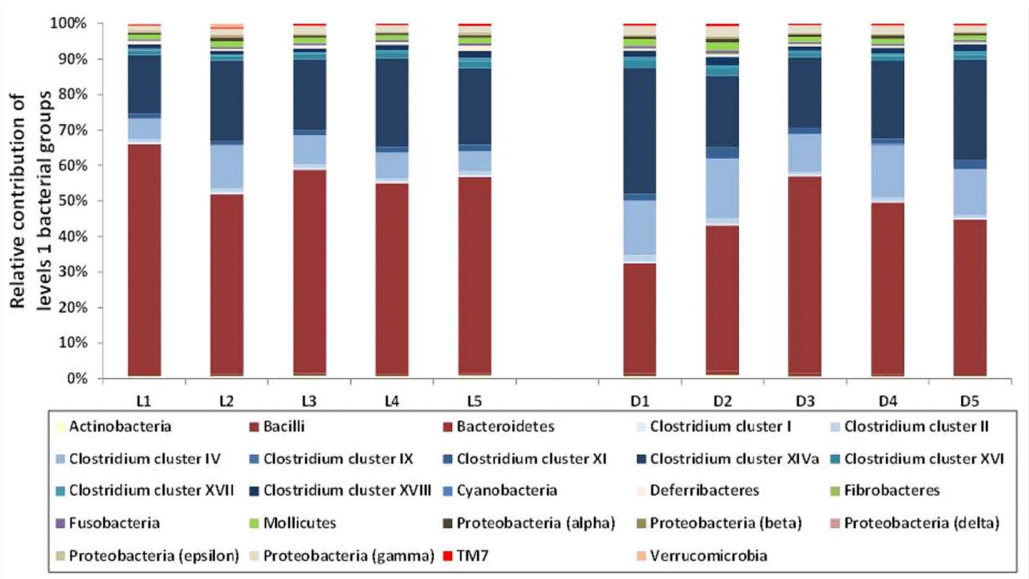

B

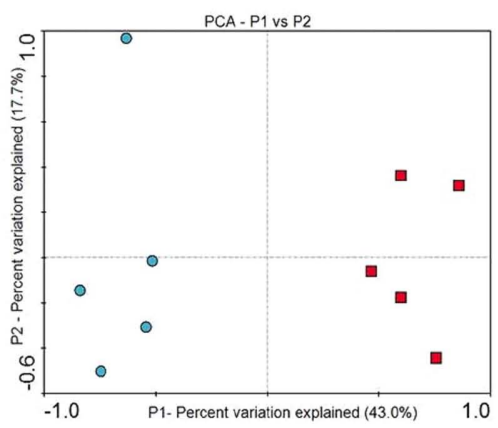

C

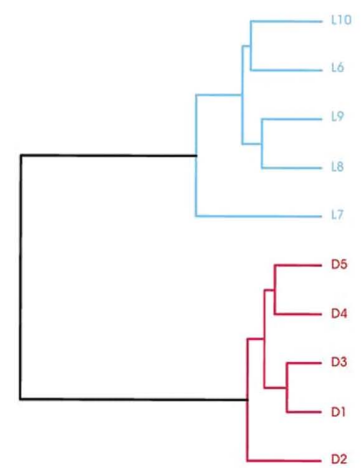

D

level 1

Actinobacteria

Bacilli

Bacteroidetes

Clostridium cluster I

Clostridium cluster II

Clostridium cluster IV

Clostridium cluster IX

Clostridium cluster $X$

Clostridium cluster $\mathrm{XVa}$

Clostridium cluster XVI

Clostridium cluster XVII

Clostridium cluster XVIII

Cyanobacteria

Deferribacteres

Fibrobacteres

Fusobacteria

Mollicutes

Proteobacteria (alpha)

Proteobacteria (beta)

Proteobacteria (delta)

Proteobacteria (epsilon)

Proteobacteria (gamma)

TM7

Verrucomicrobia

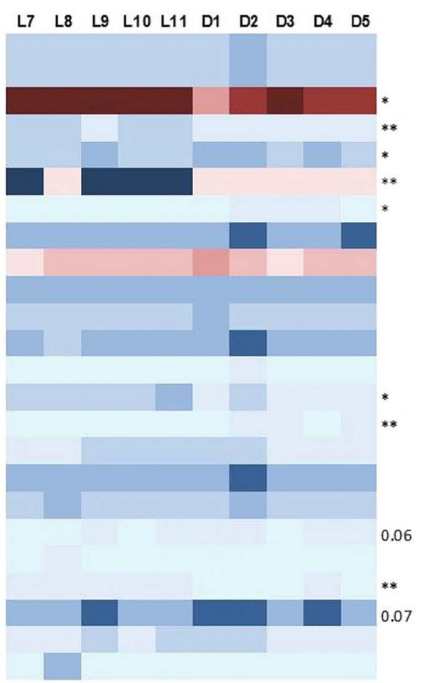

$>50>40>30>20>10>5>2>1>0.5>0.2>0$

FIGURE 2 | Phylogenetic microarray analysis of gut bacterial communities from obese diabetic mice or lean mice. (A) Percentages of each community contributed by the indicated level 1 bacterial groups. (B) PCoA analysis based on MITChip phylogenetic fingerprints of the gut microbiota from the cecal contents of $d b / d b$ and lean mice. (C) Hierarchical clustering visualizing the similarities of the phylogenetic MITChip fingerprints. Samples were hierarchically clustered based on the Pearson correlation. (D) Relative abundance of different bacterial classes expressed as the percentage of total probe signals ( $n=5$ /group). ${ }^{*} P<0.05,{ }^{*} P<0.01$ determined by a two-tailed Student's $t$-test. 



FIGURE 3 | Higher endocannabinoid system tone in the adipose tissue of $\boldsymbol{d} \boldsymbol{b} / \boldsymbol{d} \boldsymbol{b}$ mice. (A) AEAtissue content (\% of lean), (B) NAPE-PLD, (C) CB ${ }_{1}$, (D) FAAH; (E) MGL mRNA expression, and (F) 2-AG tissue content ( $\%$ of lean) measured in adipose tissue. Mean \pm SEM, $n=6 /$ group, ${ }^{*} P<0.05$ determined by a two-tailed Student's $t$-test.

multiple correlation analyses suggest a link between inflammation and the regulation of the apelinergic system (Figure A1). However, the causal link between these parameters and the regulation of apelin and APJ expression in the adipose tissue remain to be demonstrated.

Given the difficulty of deciphering the impact of low-grade inflammation (i.e., plasma LPS or cytokines) and eCB system tone on the apelinergic system in vivo, we decided to explore these mechanisms on in vitro cultured adipose tissue explants. Of note, these explants came from healthy, lean C57BL/6 mice, allowing us to investigate physiological-like or pathological-like situations, that is, eCB system tone modulation with or without a concomitant inflammatory situation.

Here, we found that the activation of the eCB system by a cannabinoid receptor agonist (HU-210) significantly decreased
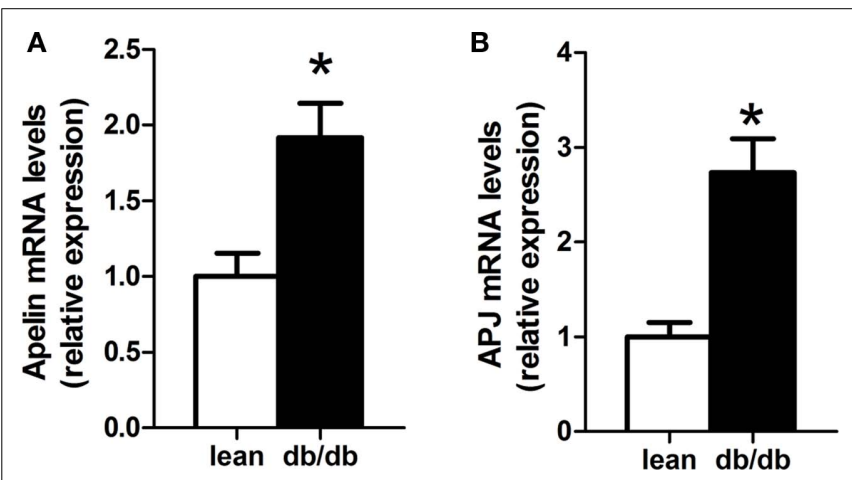

FIGURE 4 | Increased apelin and APJ mRNA expression in the adipose tissue of $\boldsymbol{d} \boldsymbol{b} / \boldsymbol{d} \boldsymbol{b}$ mice. (A) Apelin and (B) APJ mRNA expression measured in adipose tissue. Mean $\pm \mathrm{SEM}, n=6 /$ group, ${ }^{*} P<0.05$ determined by a two-tailed Student's t-test.

apelin and APJ mRNA expression (Figures 6A,B). In line with the results obtained using the cannabinoid receptor agonist in vitro, in lean wild-type mice, we found that in vivo inhibition of AEA degradation by the administration of a potent FAAH inhibitor (URB597; Kathuria et al., 2003) significantly decreased apelin and APJ mRNA expression (Figure A2). These data support the idea that the $\mathrm{eCB}$ system down-regulates the apelinergic system in physiological situations. However, we found that low-dose LPS significantly increased these two markers. More importantly, the adipose tissue explants treated with both cannabinoid receptor agonist and LPS exhibited a significant increase in apelin and APJ mRNA expression (Figures 6A,B). Altogether, this set of experiments suggests that both the $\mathrm{eCB}$ system and low-grade inflammatory tone contribute to the regulation of apelin and APJ in adipose tissue. Interestingly, concomitant stimulation with $\mathrm{eCB}$ agonist and LPS resulted in up-regulation of the apelinergic system. In parallel, we found that two key inflammatory markers (IL-1 and TNF- $\alpha$ ) were similarly up-regulated following LPS-eCB treatment (Figures 6C,D). These data further confirm that (i) both the eCB system and low-grade inflammation might be overactive during obese and type 2 diabetic situations, and (ii) that LPS and/or inflammation act as a master switch in the regulation of the apelinergic system.

\section{DISCUSSION}

This study provides new evidence for an altered gut microbiota in type 2 diabetes, independent of fat feeding. Indeed, we demonstrate that the gut microbial community is profoundly impacted by genotype and not necessarily diet because $d b / d b$ mice, compared to their littermates, exhibited a profound alteration of the gut microbiota composition. In addition, we found that some taxa are present or rather absent in diabetic mice compared to their lean littermates. These important findings question the potential impact of these bacteria in the onset of the phenotypic alterations characterizing this model. Although the microbiota analysis relied on complementary technologies and classification methods, data showed similar patterns of specific clustering of bacterial communities. We observed a decrease in the abundance of the phylum Bacteroidetes and an increase of Firmicutes. Importantly, we found 
Table 2 | Correlations between changes in the abundance of specific bacteria and adipose tissue apelin or APJ mRNA levels.

\begin{tabular}{|c|c|c|}
\hline & $r$ & $p$-Value \\
\hline \multicolumn{3}{|l|}{ Apelin } \\
\hline Acholeplasma et rel. & 0.73 & 0.0162 \\
\hline Aerococcus urinaeequi et rel. & 0.89 & 0.0005 \\
\hline Atopobium & 0.70 & 0.0255 \\
\hline Bryantella et rel. & 0.68 & 0.0296 \\
\hline Butyrivibrio crossotus et rel. & 0.67 & 0.0344 \\
\hline Catenibacterium & 0.66 & 0.0364 \\
\hline Cl. lactifermentans et rel. & 0.75 & 0.0120 \\
\hline Cl. perfringens et rel. & -0.84 & 0.0024 \\
\hline Dialister et rel. & 0.81 & 0.0043 \\
\hline Eggerthella et rel. & -0.65 & 0.0403 \\
\hline Eub. hallii et rel. & 0.74 & 0.0135 \\
\hline Helicobacter & -0.72 & 0.0181 \\
\hline Lachnospira pectinoschiza et rel. & 0.76 & 0.0110 \\
\hline L. salivarius et rel. & -0.64 & 0.0478 \\
\hline Mucispirillum schaedleri et rel. & -0.69 & 0.0276 \\
\hline Porphyromonas asaccharolytica et rel. & -0.80 & 0.0057 \\
\hline Prevotella & -0.68 & 0.0319 \\
\hline R. obeum et rel. & 0.76 & 0.0106 \\
\hline Sporobacter termitidis et rel. & 0.89 & 0.0005 \\
\hline Unc. Porphyromonadaceae & -0.86 & 0.0016 \\
\hline \multicolumn{3}{|l|}{ APJ } \\
\hline Acholeplasma et rel. & 0.74 & 0.0148 \\
\hline Aerococcus urinaeequi et rel. & 0.84 & 0.0023 \\
\hline Atopobium & 0.68 & 0.0319 \\
\hline Bryantella et rel. & 0.71 & 0.0206 \\
\hline Butyrivibrio crossotus et rel. & 0.68 & 0.0321 \\
\hline Catenibacterium & 0.72 & 0.0197 \\
\hline Cl. difficile et rel. & 0.65 & 0.0416 \\
\hline Cl. lactifermentans et rel. & 0.66 & 0.0363 \\
\hline Cl. perfringens et rel. & -0.79 & 0.0070 \\
\hline Dialister et rel. & 0.79 & 0.0065 \\
\hline Eub. hallii et rel. & 0.76 & 0.0116 \\
\hline Fibrobacter succinogenes et rel. & 0.65 & 0.0407 \\
\hline Helicobacter & -0.76 & 0.0113 \\
\hline Labrys methylaminiphilus et rel. & 0.70 & 0.0236 \\
\hline Lachnospira pectinoschiza et rel. & 0.72 & 0.0179 \\
\hline L. gasseri et rel. & 0.67 & 0.0341 \\
\hline L. salivarius et rel. & -0.67 & 0.0333 \\
\hline Porphyromonas asaccharolytica et rel. & -0.76 & 0.0101 \\
\hline R. obeum et rel. & 0.64 & 0.0479 \\
\hline Sporobacter termitidis et rel. & 0.85 & 0.0017 \\
\hline Unc. Porphyromonadaceae & -0.86 & 0.0013 \\
\hline
\end{tabular}

a dramatic increase of Proteobacteria following the pyrosequencing method. Moreover, ten genera whose abundance was significantly affected by the genotype have been identified. Interestingly, we identified several taxa of Gram-negative bacteria at significantly higher frequencies or exclusively in $d b / d b$ mice. Because LPS from Gram-negative bacteria triggered low-grade inflammation and stimulated apelin and APJ expression, we postulate that these specific changes contributed to the phenotype observed in $d b / d b$ mice compared to their lean counterparts. In addition to
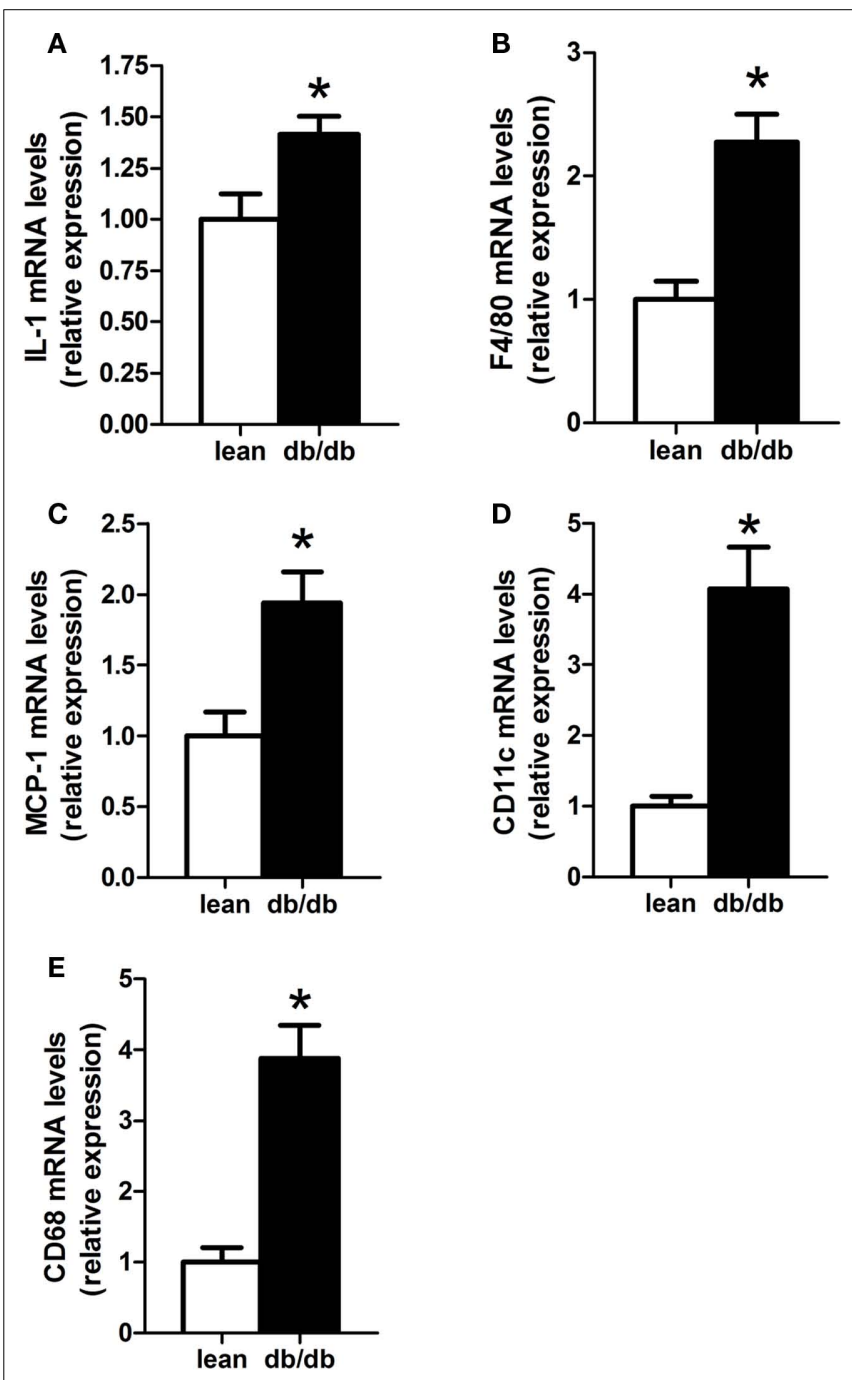

FIGURE 5 | Increased inflammatory markers in the adipose tissue of $\boldsymbol{d} \boldsymbol{b} / \boldsymbol{d} \boldsymbol{b}$ mice. (A) IL-1, (B) F4/80, (C) MCP-1, (D) CD11C, and (E) CD68 $m R N A$ expression measured in adipose tissue. Mean \pm SEM, $n=6 /$ group, ${ }^{*} P<0.05$ determined by a two-tailed Student's $t$-test.

the putative higher content of LPS within the intestinal lumen, it has been previously shown that $d b / d b$ mice are characterized by greater intestinal inflammation and gut permeability (Brun et al., 2007; Duparc et al., 2011b). Therefore, in addition to the dysfunction of the leptin action characterizing this mouse model, we propose that the shift in the gut microbial community observed also contributed to the development of the complex phenotype found in $d b / d b$ mice. Nevertheless, given the complexity of these modifications and the number of correlations found, the direct association between one or more specific taxa and the changes affecting host physiology remain to be investigated. Hence, further work is required to understand the functional links between the metabolic/catabolic activities of gut bacteria and their impact on host metabolism. For instance, it would be of interest to investigate this genetic model in a germ-free situation to identify the specific impact of the gut microbes on the onset of type 2 diabetes. Importantly, when we compared the classification results from pyrosequencing to those obtained from phylogenetic microarrays, 

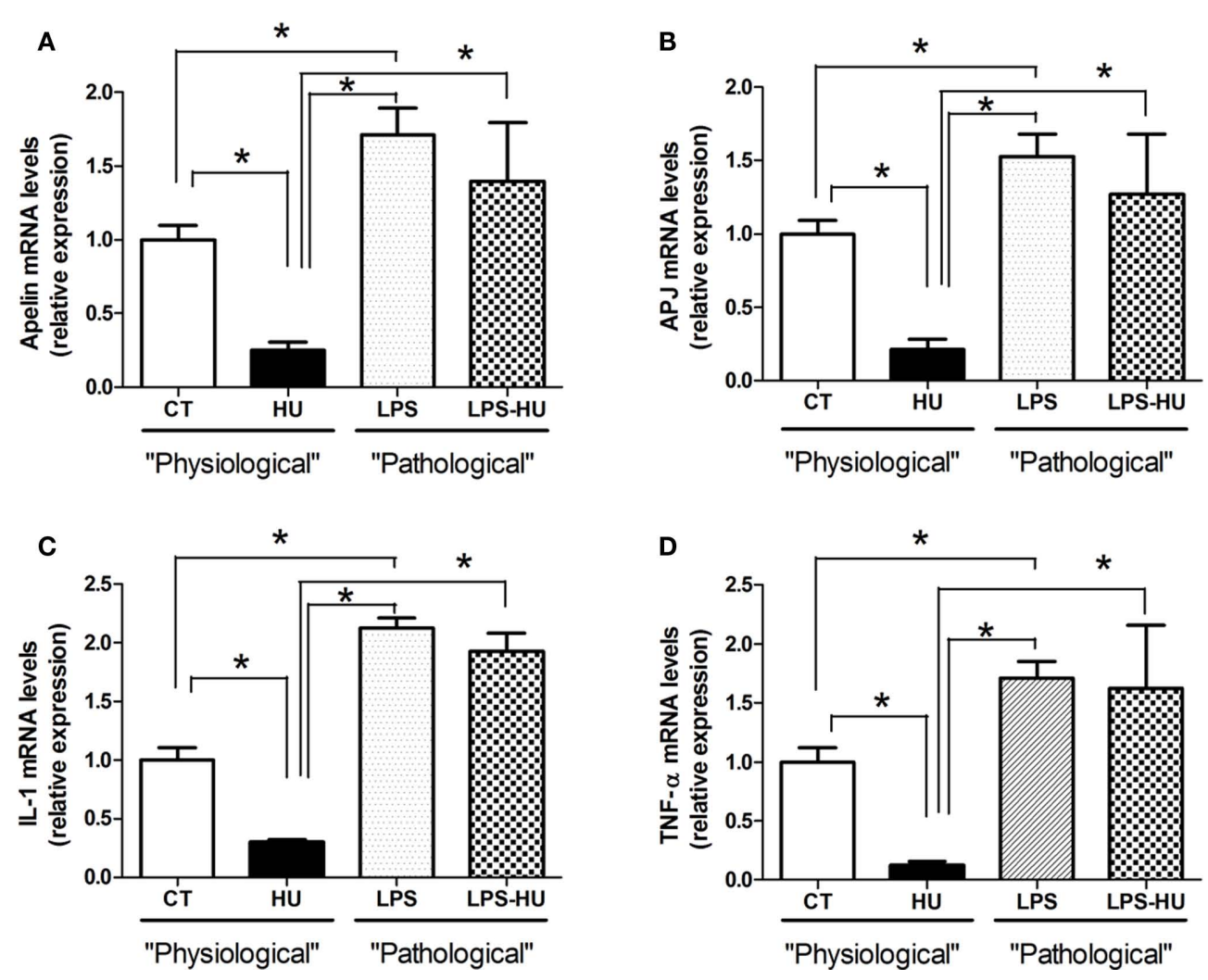

FIGURE 6 |The eCB system down-regulates LPS-induced inflammation (IL-1 and TNF- $\alpha$ mRNA expression) and the apelinergic system (apelin and APJ mRNA expression) in adipose tissue explant cultures. mRNA expression levels of (A) Apelin, (B) APJ, (C) IL-1, and (D) TNF- $\alpha$ in cultured

we observed more differences attributed to a deeper analysis of the phylogenetic microarrays ( $<0.1 \%$ of the community; RajilicStojanovic et al., 2009) than pyrosequencing. Recently the impact of use of different primers was assessed by 454 pyrosequencing and could impact the microbial profiling (van den Bogert et al., 2011), off note, deep pyrosequencing and phylogenetic microarrays provided similar biological conclusions, although the classification may be different from that in previously reported systems (Claesson et al., 2009).

This study also provided novel mechanisms involving the important roles of the eCB and low-grade inflammatory tone in the regulation of one specific adipokine and its receptor, namely, apelin and APJ. Hence, multiple correlation analyses suggest that specific gut microbes positively or negatively correlate with apelin and APJ mRNA. This study also supports the interest of combining high-throughput culture-independent approaches with physiological assessments to define the relationships between gut microbial communities and host metabolism. Nevertheless, given the complexity of these biological systems, the direct association between one or more bacterial groups and the changes affecting host physiology remain to be confirmed.

During the last years, numerous studies have demonstrated a clear relationship between energy metabolism and peripheral apelin action. Under pathophysiological conditions, the peripheral apelinergic system seems to be deregulated (Dray et al., 2008, 2010; Duparc et al., 2011a). While some researchers found that levels of plasma apelin in humans and mice were increased in obese diabetes (Heinonen et al., 2005; Dray et al., 2008) and in the insulin resistance state (Soriguer et al., 2009), others demonstrated that plasma apelin was reduced in type 2 diabetes patients (Erdem et al., 2008). Recently, it has been highlighted that the severity of insulin resistance might influence the regulation of apelin and APJ expression (Dray et al., 2010).

In this study, we first demonstrated the presence of an increase in $\mathrm{eCB}$ system tone (higher AEA levels, NAPE-PLD, and $\mathrm{CB}_{1}$ expression and lower FAAH expression) in the adipose tissue of $d b / d b$ mice. Here we show for the first time that AEA levels are increased in adipose tissue and are in accordance with our previous findings (Muccioli et al., 2010). In parallel, we found that both apelin and APJ expression were significantly increased. By using multiple correlation analyses, we observed very strong relationships between the $\mathrm{eCB}$ system and the apelinergic system, supporting the potential implication of the eCB system in apelinergic tone. However, $d b / d b$ mice were also characterized by a higher inflammatory tone (Brun et al., 2007), which is, according to our results, positively and significantly correlated with apelin/APJ. Given that $d b / d b$ mice also exhibited better eCB system tone and inflammation, we investigated the 
direct impact of the endocannabinoids. To clarify this issue, we increased endogenous AEA levels in the adipose tissue of lean mice following the inhibition of FAAH (Muccioli et al., 2010), the main AEA-degrading enzyme (Muccioli, 2010). Strikingly, we found that this procedure significantly decreased apelin and APJ expression. Similarly to these in vivo data, the stimulation of adipose tissue explants with cannabinoid agonist profoundly reduced the expression of apelin and APJ. Furthermore, knowing that $d b / d b$ mice developed a low-grade inflammatory tone, possibly linked to gut microbiota-derived LPS, we investigated the role of LPS in the regulation of these peptides. Interestingly, we demonstrated that LPS directly increased apelinergic system tone in adipose tissue. We also found that LPS treatment completely counteracted the eCB-dependent down-regulation of apelin and APJ. Taken together, all these data strongly support the concept that both systems are implicated in the regulation of apelinergic tone. However, both our in vivo and in vitro data point to inflammation as a master control in this cross-talk. Based on these data, we postulate that, in physiological conditions, eCB system tone participates in the down-regulation of the apelinergic system, whereas in pathological conditions, the low-grade inflammatory tone acts as a master switch to increase both $\mathrm{eCB}$ system tone and the apelinergic system. Although our data relied on different regulatory mechanisms (eCB tone

\section{REFERENCES}

Backhed, F., Ding, H., Wang, T., Hooper, L. V., Koh, G. Y., Nagy, A., Semenkovich, C. F., and Gordon, J. I. (2004). The gut microbiota as an environmental factor that regulates fat storage. Proc. Natl. Acad. Sci. U.S.A 101, 15718-15723.

Bluher, M., Engeli, S., Kloting, N., Berndt, J., Fasshauer, M., Batkai, S., Pacher, P., Schon, M. R., Jordan, J., and Stumvoll, M. (2006). Dysregulation of the peripheral and adipose tissue endocannabinoid system in human abdominal obesity. Diabetes 55, 3053-3060.

Brun, P., Castagliuolo, I., Leo, V. D., Buda, A., Pinzani, M., Palu, G., and Martines, D. (2007). Increased intestinal permeability in obese mice: new evidence in the pathogenesis of nonalcoholic steatohepatitis. Am. J. Physiol. Gastrointest. Liver Physiol. 292, G518-G525.

Cani, P. D., Amar, J., Iglesias, M. A., Poggi, M., Knauf, C., Bastelica, D., Neyrinck, A. M., Fava, F., Tuohy, K. M., Chabo, C., Waget, A., Delmee, E., Cousin, B., Sulpice, T., Chamontin, B., Ferrieres, J., Tanti, J. F., Gibson, G. R., Casteilla, L., Delzenne, N. M., Alessi, M. C., and Burcelin, R. (2007a). Metabolic endotoxemia initiates obesity and insulin resistance. Diabetes 56, 1761-1772.

Cani, P. D., Neyrinck, A. M., Fava, F., Knauf, C., Burcelin, R. G., Tuohy, K. M., Gibson, G. R., and Delzenne, N. M. (2007b). Selective increases of bifidobacteria in gut microflora improve highfat-diet-induced diabetes in mice through a mechanism associated with endotoxaemia. Diabetologia 50 , 2374-2383.

Cani, P. D., Bibiloni, R., Knauf, C., Waget, A., Neyrinck, A. M., Delzenne, N. M., and Burcelin, R. (2008). Changes in gut microbiota control metabolic endotoxemia-induced inflammation in high-fat diet-induced obesity and diabetes in mice. Diabetes 57, 1470-1481.

Cani, P. D., and Delzenne, N. M. (2011). The gut microbiome as therapeutic target. Pharmacol. Ther. 130, 202-212.

Cani, P. D., Possemiers, S., Van de, W. T., Guiot, Y., Everard, A., Rottier, O., Geurts, L., Naslain, D., Neyrinck, A. M., Lambert, D. M., Muccioli, G. G., and Delzenne, N. M. (2009). Changes in gut microbiota control inflammation in obese mice through a mechanism involving GLP-2-driven improvement of gut permeability. Gut 58, 1091-1103.

and metabolic endotoxemia), both are clearly associated with gut microbiota composition (Cani and Delzenne, 2011). Thus, understanding the complexity of gut microbiota is increasingly important for deciphering potential interactions between hosts and microbes.

In conclusion, we have demonstrated that the $\mathrm{eCB}$ and lowgrade inflammatory tone are closely involved in the regulation of apelin and APJ expression in adipose tissue. Moreover, we found that genetic obese and type 2 diabetic mice harbored profound changes in their gut microbiota compositions compared to their lean counterparts. Although we found strong positive and negative relationships between specific bacteria and the apelinergic system, the exact implications of several bacteria for shaping the phenotype of these mice remain to be studied.

\section{ACKNOWLEDGMENTS}

Patrice D. Cani is a research associate from the FRS-FNRS (Fonds de la Recherche Scientifique) in Belgium. Jacques Schrenzel and Patrice François were supported by grants from the Swiss National Science Foundation, \#31003A-124717/1 and 3100A0116075, respectively. Nathalie M. Delzenne and Patrice D. Cani are recipients of FSR and FRSM grants (Fonds spéciaux de recherches, UCL, Belgium; Fonds de la recherche scientifique médicale, Belgium).

Claesson, M. J., O’Sullivan, O., Wang, Q., Nikkila, J., Marchesi, J. R., Smidt, H., de Vos, W. M., Ross, R. P., and O’Toole, P. W. (2009). Comparative analysis of pyrosequencing and a phylogenetic microarray for exploring microbial community structures in the human distal intestine. PLoS. ONE 4, e6669. doi: 10.1371/journal.pone.0006669

Cole, J. R., Wang, Q., Cardenas, E., Fish, J., Chai, B., Farris, R. J., KulamSyed-Mohideen, A. S., McGarrell, D. M., Marsh, T., Garrity, G. M. and Tiedje, J. M. (2009). The ribosomal database project: improved alignments and new tools for rRNA analysis. Nucleic Acids Res. 37, D141-D145.

Cote, M., Matias, I., Lemieux, I., Petrosino, S., Almeras, N., Despres, J. P., and Di, Marzo V. (2007). Circulating endocannabinoid levels, abdominal adiposity and related cardiometabolic risk factors in obese men. Int. J. Obes. (Lond.) 31, 692-699.

Cravatt, B. F., Giang, D. K., Mayfield, S. P., Boger, D. L., Lerner, R. A., and Gilula, N. B. (1996). Molecular characterization of an enzyme that degrades neuromodulatory fatty-acid amides. Nature 384 83-87.

Daviaud, D., Boucher, J., Gesta, S. Dray, C., Guigne, C., Quilliot,
D., Ayav, A., Ziegler, O., Carpene, C., Saulnier-Blache, J. S., Valet, P., and Castan-Laurell, I. (2006). TNFalpha up-regulates apelin expression in human and mouse adipose tissue. FASEB J. 20, 1528-1530.

De La Serre, C. B., Ellis, C. L., Lee, J., Hartman, A. L., Rutledge, J. C., and Raybould, H. E. (2010). Propensity to high-fat diet-induced obesity in rats is associated with changes in the gut microbiota and gut inflammation. Am. J. Physiol. Gastrointest. Liver Physiol. 299, G440-G448.

Deng, Y., and Scherer, P. E. (2010). Adipokines as novel biomarkers and regulators of the metabolic syndrome. Ann. N. Y. Acad. Sci. 1212, E1-E19.

D'Eon, T. M., Pierce, K. A., Roix, J. J., Tyler, A., Chen, H., and Teixeira, S. R. (2008). The role of adipocyte insulin resistance in the pathogenesis of obesity-related elevations in endocannabinoids. Diabetes 57, 1262-1268.

Devane, W. A., Hanus, L., Breuer, A., Pertwee, R. G., Stevenson, L. A., Griffin, G., Gibson, D., Mandelbaum, A., Etinger, A., and Mechoulam, R. (1992). Isolation and structure of a brain constituent that binds to the cannabinoid receptor. Science 258, 1946-1949. 
Dinh, T. P., Carpenter, D., Leslie, F. M., Freund, T. F., Katona, I., Sensi, S. L., Kathuria, S., and Piomelli, D. (2002). Brain monoglyceride lipase participating in endocannabinoid inactivation. Proc. Natl. Acad. Sci. U.S.A 99, 10819-10824.

Dray, C., Debard, C., Jager, J., Disse, E., Daviaud, D., Martin, P., Attane, C., Wanecq, E., Guigne, C., Bost, F., Tanti, J. F., Laville, M., Vidal, H., Valet, P., and Castan-Laurell, I. (2010). Apelin and APJ regulation in adipose tissue and skeletal muscle of type 2 diabetic mice and humans. Am. J. Physiol. Endocrinol. Metab. 298, E1161-E1169.

Dray, C., Knauf, C., Daviaud, D., Waget, A., Boucher, J., Buleon, M., Cani, P. D., Attane, C., Guigne, C., Carpene, C., Burcelin, R., Castan-Laurell, I., and Valet, P. (2008). Apelin stimulates glucose utilization in normal and obese insulin-resistant mice. Cell Metab. 8, 437-445.

Duparc, T., Colom, A., Cani, P. D., Massaly, N., Rastrelli, S., Drougard, A., Le, G. S., Mouledous, L., Frances, B., Leclercq, I., Llores-Cortes, C., Pospisilik, J. A., Delzenne, N. M., Valet, P., Castan-Laurell, I., and Knauf, C. (2011a). Central apelin controls glucose homeostasis via a nitric oxide dependent pathway in mice. Antioxid. Redox Signal. doi: 10.1089/ars.2010.3454. [Epub ahead of print].

Duparc, T., Naslain, D., Colom, A., Muccioli, G. G., Massaly, N., Delzenne, N. M., Valet, P., Cani, P. D., and Knauf, C. (2011b). Jejunum inflammation in obese and diabetic mice impairs enteric glucose detection and modifies nitric oxide release in the hypothalamus. Antioxid. Redox Signal. 14, 415-423.

Edgar, R. C. (2004). Muscle: multiple sequence alignment with high accuracy and high throughput. Nucleic Acids Res. 32, 1792-1797.

Engeli, S., Bohnke, J., Feldpausch, M., Gorzelniak, K., Janke, J., Batkai, S., Pacher, P., Harvey-White, J., Luft, F. C., Sharma, A. M., and Jordan, J. (2005). Activation of the peripheral endocannabinoid system in human obesity. Diabetes 54, 2838-2843.

Erdem, G., Dogru, T., Tasci, I., Sonmez, A., and Tapan, S. (2008). Low plasma apelin levels in newly diagnosed type 2 diabetes mellitus. Exp. Clin. Endocrinol. Diabetes 116, 289-292.

Federico, A., D'Aiuto, E., Borriello, F., Barra, G., Gravina, A. G., Romano, M., and De, P. R. (2010). Fat: a matter of disturbance for the immune system. World J. Gastroenterol. 16, 4762-4772.

Hamady, M., Walker, J. J., Harris, J. K., Gold, N. J., and Knight, R. (2008). Error-correcting barcoded primers for pyrosequencing hundreds of samples in multiplex. Nat. Methods 5, 235-237.

Han, S., Wang, G., Qi, X., Englander, E. W., and Greeley, G. H. Jr. (2008a). Involvement of a Stat 3 binding site in inflammationinduced enteric apelin expression. Am. J. Physiol. Gastrointest. Liver Physiol. 295, G1068-G1078.

Han, S., Wang, G., Qi, X., Lee, H. M., Englander, E. W., and Greeley, G. H. Jr. (2008b). A possible role for hypoxia-induced apelin expression in enteric cell proliferation. Am. J. Physiol. Regul. Integr. Comp. Physiol. 294, R1832-R1839.

Heinonen, M. V., Purhonen, A. K., Miettinen, P., Paakkonen, M., Pirinen, E., Alhava, E., Akerman, K., and Herzig, K. H. (2005). Apelin, orexin-A and leptin plasma levels in morbid obesity and effect of gastric banding. Regul. Pept. 130, 7-13.

Hellmann, J., Tang, Y., Kosuri, M., Bhatnagar, A., and Spite, M. (2011). Resolvin D1 decreases adipose tissue macrophage accumulation and improves insulin sensitivity in obese-diabetic mice. FASEB J. 25, 2399-2407.

Hildebrandt, M. A., Hoffmann, C., Sherrill-Mix, S. A., Keilbaugh, S. A., Hamady, M., Chen, Y. Y., Knight, R., Ahima, R. S., Bushman, F., and Wu, G. D. (2009). High-fat diet determines the composition of the murine gut microbiome independently of obesity. Gastroenterology 137, 1716-1724.

Huang, Y., Niu, B., Gao, Y., Fu, L., and Li, W. (2010). CD-HIT Suite: a web server for clustering and comparing biological sequences. Bioinformatics 26, 680-682.

Izzo, A. A., Piscitelli, F., Capasso, R., Aviello, G., Romano, B., Borrelli, F., Petrosino, S., and Di, M. V. (2009). Peripheral endocannabinoid dysregulation in obesity: relation to intestinal motility and energy processing induced by food deprivation and re-feeding. Br. J. Pharmacol. 158, 451-461.

Kathuria, S., Gaetani, S., Fegley, D., Valino, F., Duranti, A., Tontini, A., Mor, M., Tarzia, G., La, R. G., Calignano, A., Giustino, A., Tattoli, M., Palmery, M., Cuomo, V., and Piomelli, D. (2003). Modulation of anxiety through blockade of anandamide hydrolysis. Nat. Med. 9, 76-81.
Lambert, D. M., and Muccioli, G. G. (2007). Endocannabinoids and related $\mathrm{N}$-acylethanolamines in the control of appetite and energy metabolism: emergence of new molecular players. Curr. Opin. Clin. Nutr. Metab. Care 10, 735-744.

Lazarevic, V., Whiteson, K., Hernandez, D., Francois, P., and Schrenzel, J. (2010). Study of inter- and intraindividual variations in the salivary microbiota. BMC Genomics 11, 523 . doi: 10.1186/1471-2164-11-523

Ley, R. E., Backhed, F., Turnbaugh, P., Lozupone, C. A., Knight, R. D., and Gordon, J. I. (2005). Obesity alters gut microbial ecology. Proc. Natl. Acad. Sci. U.S.A 102, 11070-11075.

Ley, R. E., Turnbaugh, P. J., Klein, S., and Gordon, J. I. (2006). Microbial ecology: human gut microbes associated with obesity. Nature 444 1022-1023.

Liu, J., Batkai, S., Pacher, P., HarveyWhite, J., Wagner, J. A., Cravatt, B. F., Gao, B., and Kunos, G. (2003). Lipopolysaccharide induces anandamide synthesis in macrophages via CD14/MAPK/phosphoinositide 3-kinase/NF-kappaB independently of platelet-activating factor. J. Biol Chem. 278, 45034-45039.

Lozupone, C., Hamady, M., and Knight, R. (2006). UniFrac - an online tool for comparing microbial community diversity in a phylogenetic context. BMC Bioinformatics 7, 371. doi: 10.1186/1471-2105-7-371

Maenhaut, N., and Van, D. V. (2011) Regulation of vascular tone by adipocytes. BMC Med. 9, 25. doi: 10.1186/1741-7015-9-25

Martin, F. P., Wang, Y., Sprenger, N., Yap, I. K., Rezzi, S., Ramadan, Z., PereTrepat, E., Rochat, F., Cherbut, C., van, B. P., Fay, L. B., Kochhar, S., Lindon, J. C., Holmes, E., and Nicholson, J. K. (2008). Top-down systems biology integration of conditional prebiotic modulated transgenomic interactions in a humanized microbiome mouse model. Mol. Syst. Biol. 4, 205.

Martinez, I., Wallace, G., Zhang, C. Legge, R., Benson, A. K., Carr, T. P., Moriyama, E. N., and Walter, J. (2009). Diet-induced metabolic improvements in a hamster model of hypercholesterolemia are strongly linked to alterations of the gut microbiota. Appl. Environ. Microbiol. 75, 4175-4184.

Matias, I., Gonthier, M. P., Orlando, P., Martiadis, V., De, P. L., Cervino, C., Petrosino, S., Hoareau, L., Festy, F., Pasquali, R., Roche, R., Maj, M., Pagotto, U., Monteleone, P., and Di, M. V. (2006). Regulation, function, and dysregulation of endocannabinoids in models of adipose and betapancreatic cells and in obesity and hyperglycemia. J. Clin. Endocrinol. Metab. 91, 3171-3180.

Melgar-Lesmes, P., Pauta, M., Reichenbach, V., Casals, G., Ros, J., Bataller, R., Morales-Ruiz, M., and Jimenez, W. (2011). Hypoxia and proinflammatory factors upregulate apelin receptor expression in human stellate cells and hepatocytes. Gut. doi: 10.1136/gut.2010.234690. [Epub ahead of print].

Meyer, F., Paarmann, D., D’Souza, M., Olson, R., Glass, E. M., Kubal, M., Paczian, T., Rodriguez, A., Stevens, R., Wilke, A., Wilkening, J., and Edwards, R. A. (2008). The metagenomics RAST server - a public resource for the automatic phylogenetic and functional analysis of metagenomes. BMC Bioinformatics 9, 386. doi: 10.1186/1471-2105-9386

Mihara, M., Aihara, K., Ikeda, Y., Yoshida, S., Kinouchi, M., Kurahashi, K., Fujinaka, Y., Akaike, M., and Matsumoto, T. (2010). Inhibition of thrombin action ameliorates insulin resistance in type 2 diabetic $\mathrm{db} / \mathrm{db}$ mice. Endocrinology 151, 513-519.

Muccioli, G. G. (2010). Endocannabinoid biosynthesis and inactivation, from simple to complex. Drug Discov. Today 15, 474-483.

Muccioli, G. G., Naslain, D., Backhed, F., Reigstad, C. S., Lambert, D. M., Delzenne, N. M., and Cani, P. D. (2010). The endocannabinoid system links gut microbiota to adipogenesis. Mol. Syst. Biol. 6, 392.

Muccioli, G. G., and Stella, N. (2008). An optimized GC-MS method detects nanomolar amounts of anandamide in mouse brain. Anal. Biochem. 373, 220-228.

Olefsky, J. M., and Glass, C. K. (2010) Macrophages, inflammation, and insulin resistance. Annu. Rev. Physiol. 72, 219-246.

Price, M. N., Dehal, P. S., and Arkin, A. P. (2009). FastTree: computing large minimum evolution trees with profiles instead of a distance matrix. Mol. Biol. Evol. 26, 1641-1650.

Rajilic-Stojanovic, M., Heilig, H. G., Molenaar, D., Kajander, K., Surakka, A., Smidt, H., and de Vos, W. M. (2009). Development and application of the human intestinal tract chip, a phylogenetic microarray: analysis of universally conserved phylotypes in the abundant microbiota of young and elderly adults. Environ. Microbiol. 11, 1736-1751. 
Soriguer, F., Garrido-Sanchez, L., Garcia-Serrano, S., Garcia-Almeida, J. M., Garcia-Arnes, J., Tinahones, F. J., and Garcia-Fuentes, E. (2009). Apelin levels are increased in morbidly obese subjects with type 2 diabetes mellitus. Obes. Surg. 19, 1574-1580.

Sorli, S. C., van den Berghe, L., Masri, B., Knibiehler, B., and Audigier, Y. (2006). Therapeutic potential of interfering with apelin signalling. Drug Discov. Today 11, 1100-1106.

Starowicz, K. M., Cristino, L., Matias, I., Capasso, R., Racioppi, A., Izzo, A. A., and Di, M. V. (2008). Endocannabinoid dysregulation in the pancreas and adipose tissue of mice fed with a high-fat diet. Obesity (Silver. Spring) $16,553-565$.

Turnbaugh, P. J., Backhed, F., Fulton, L., and Gordon, J. I. (2008). Diet-induced obesity is linked to marked but reversible alterations in the mouse distal gut microbiome. Cell Host Microbe 3, 213-223.

Turnbaugh, P. J., Ley, R. E., Mahowald, M. A., Magrini, V., Mardis, E. R., and Gordon, J. I. (2006). An obesityassociated gut microbiome with increased capacity for energy harvest. Nature 444, 1027-1031.

Turnbaugh, P. J., Ridaura, V. K., Faith, J. J., Rey, F. E., Knight, R., and Gordon, J. I. (2009). The effect of diet on the human gut microbiome: a metagenomic analysis in humanized gnotobiotic mice. Sci. Transl. Med. 1, 6ra14. van den Bogert, B., de Vos, W. M., Zoetendal, E. G., and Kleerebezem, M. (2011). Microarray analysis and barcoded pyrosequencing provide consistent microbial profiles depending on the source of human intestinal samples. Appl. Environ. Microbiol. 77, 2071-2080.

Vijay-Kumar, M., Aitken, J. D., Carvalho, F. A., Cullender, T. C., Mwangi,
S., Srinivasan, S., Sitaraman, S. V., Knight, R., Ley, R. E., and Gewirtz, A. T. (2010). Metabolic syndrome and altered gut microbiota in mice lacking Toll-like receptor 5. Science 328, 228-231.

Wang, Q., Garrity, G. M., Tiedje, J. M., and Cole, J. R. (2007). Naive Bayesian classifier for rapid assignment of rRNA sequences into the new bacterial taxonomy. Appl. Environ. Microbiol. 73, 5261-5267.

Conflict of Interest Statement: The authors declare that the research was conducted in the absence of any commercial or financial relationships that could be construed as a potential conflict of interest.

Received: 31 March 2011; accepted: 26 June 2011; published online: 13 July 2011.
Citation: Geurts L, Lazarevic V, Derrien $M$, Everard A, Van Roye $M$, Knauf $C$, Valet P, Girard M, Muccioli GG, François $P$, de Vos WM, Schrenzel J, Delzenne NM and Cani PD (2011) Altered gut microbiota and endocannabinoid system tone in obese and diabetic leptin-resistant mice: impact on apelin regulation in adipose tissue. Front. Microbio. 2:149. doi: 10.3389/fmicb.2011.00149

This article was submitted to Frontiers in Cellular and Infection Microbiology, a specialty of Frontiers in Microbiology. Copyright (c) 2011 Geurts, Lazarevic, Derrien, Everard, Van Roye, Knauf, Valet, Girard, Muccioli, François, de Vos, Schrenzel, Delzenne and Cani. This is an open-access article subject to a nonexclusive license between the authors and Frontiers Media SA, which permits use, distribution and reproduction in other forums, provided the original authors and source are credited and other Frontiers conditions are complied with. 

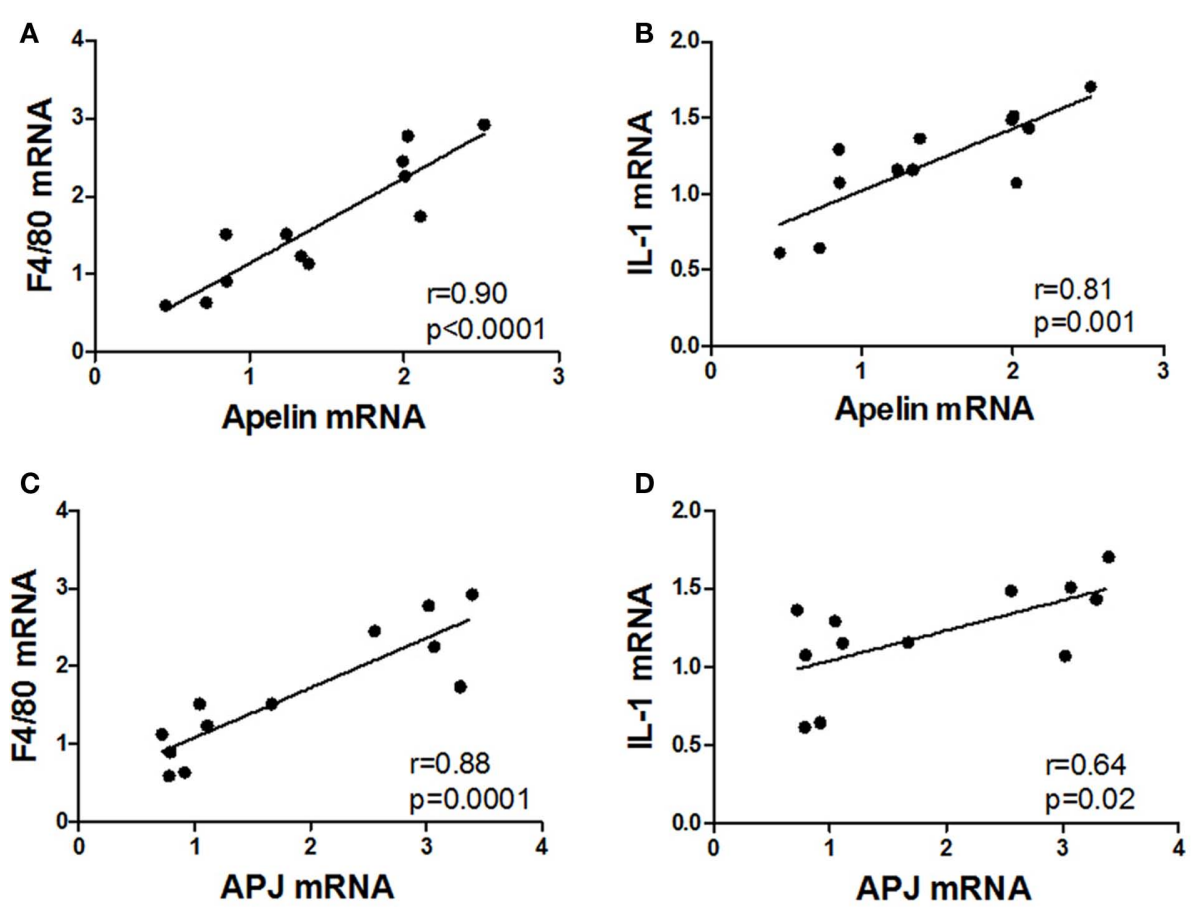

FIGURE A1 | Multiple correlation analyses between the apelinergic system and inflammation. Pairwise correlations between F4/80 or IL-1 and apelin $(\mathbf{A}, \mathbf{B})$ or APJ (C,D) mRNA expression measured in the adipose tissue of $d b / d b$ mice. Insets in each graph depict Pearson's correlation value of the coefficient ( $r$ ) and $P$ values.

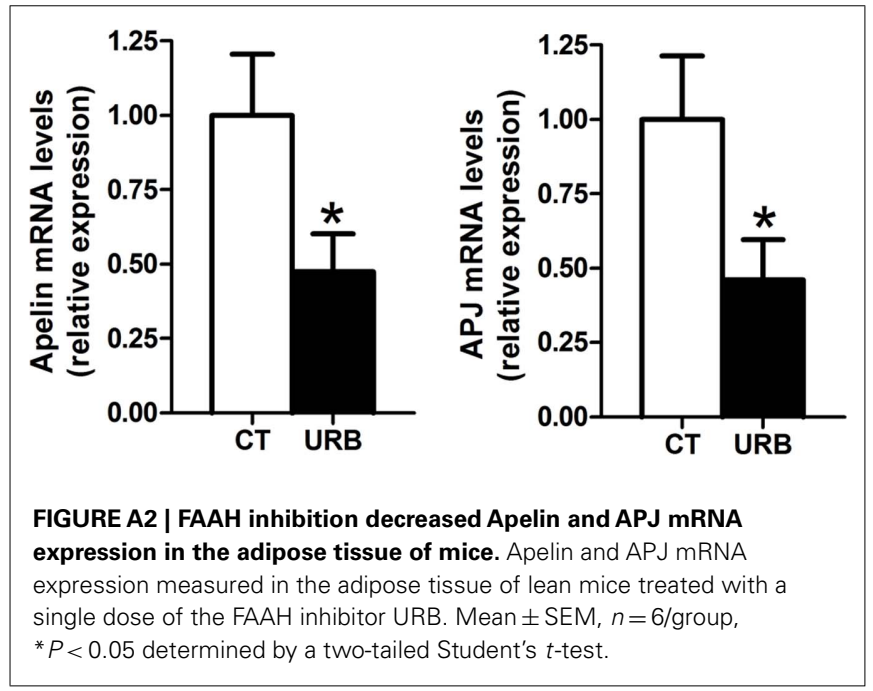

TABLE A1 | Sequencing statistics for 10 cecal microbiomes.

\begin{tabular}{llll}
\hline Primer barcode & Number of filtered sequences & Mouse ID & Group \\
\hline 692 & 3470 & 1 & $d b / d b$ \\
693 & 2754 & 2 & $d b / d b$ \\
694 & 3077 & 3 & $d b / d b$ \\
695 & 3038 & 4 & $d b / d b$ \\
696 & 3564 & 5 & $d b / d b$ \\
697 & 2558 & 6 & lean \\
698 & 3314 & 7 & lean \\
699 & 2920 & 8 & lean \\
700 & 3707 & 9 & lean \\
701 & 3175 & 10 & lean \\
\hline
\end{tabular}

Reverse PCR primers contained barcode sequences described by Hamady et al. (2008). 







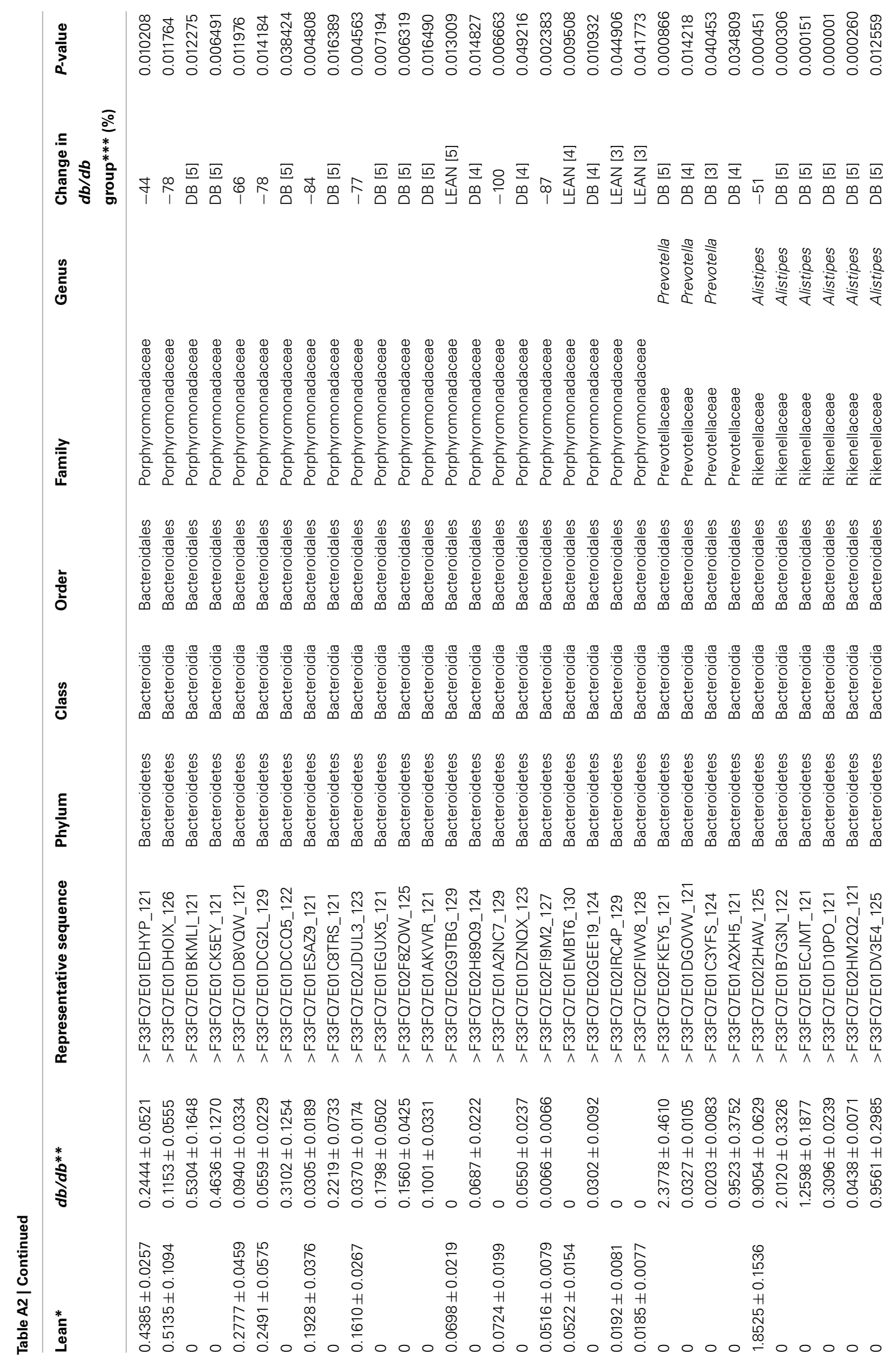




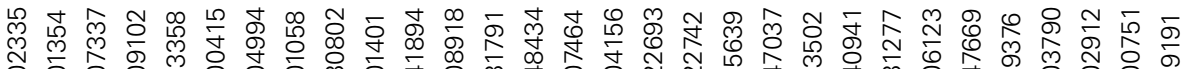

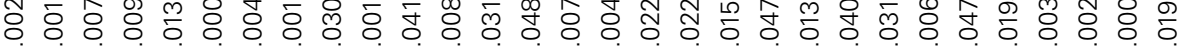

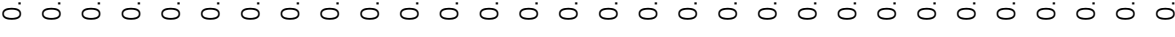

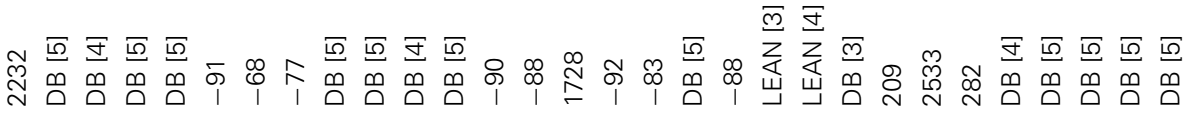

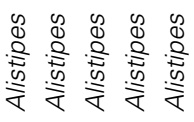

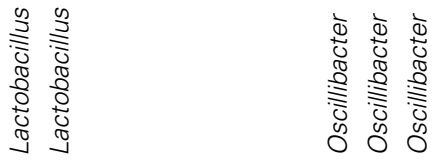
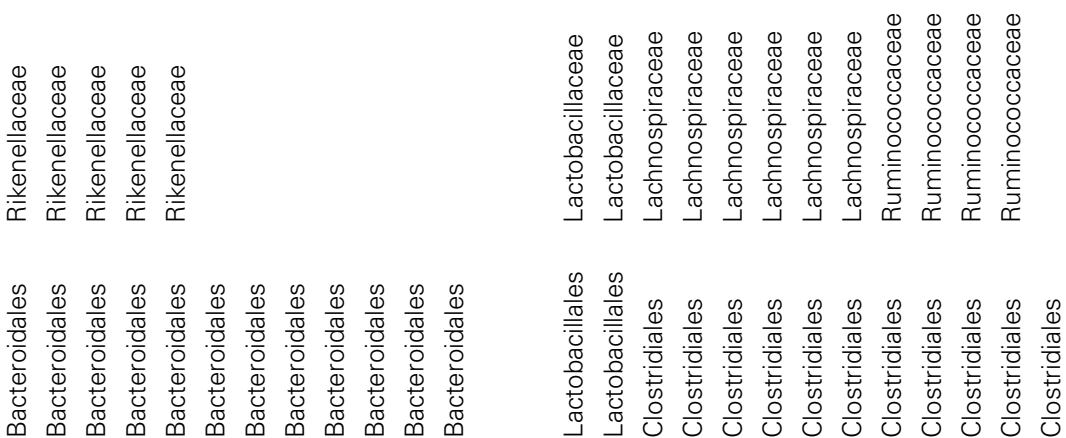

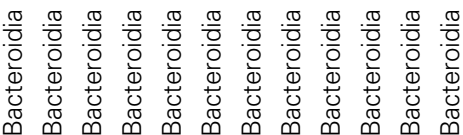
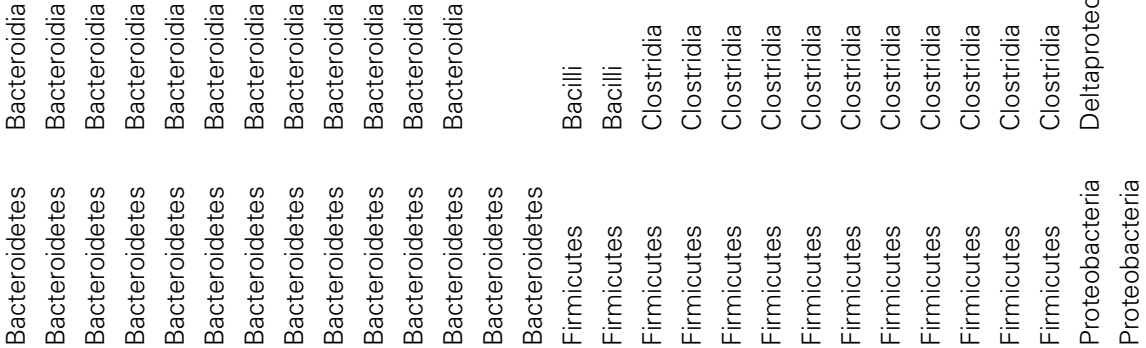

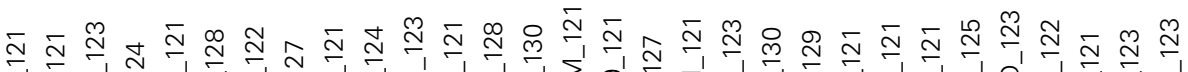

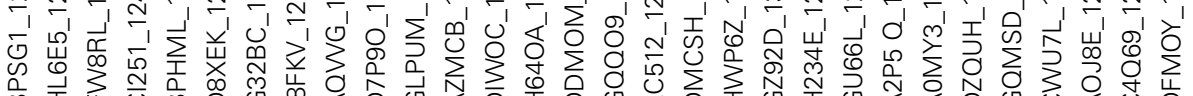

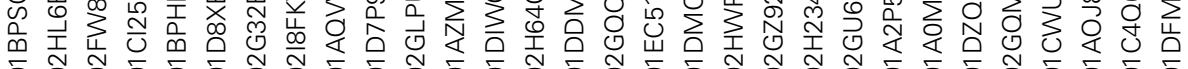

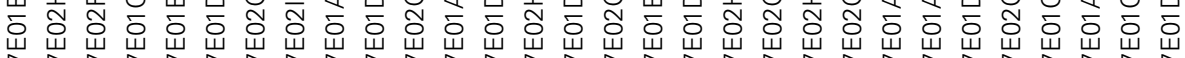

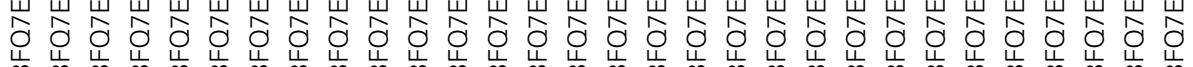

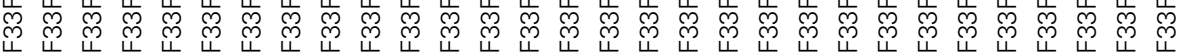
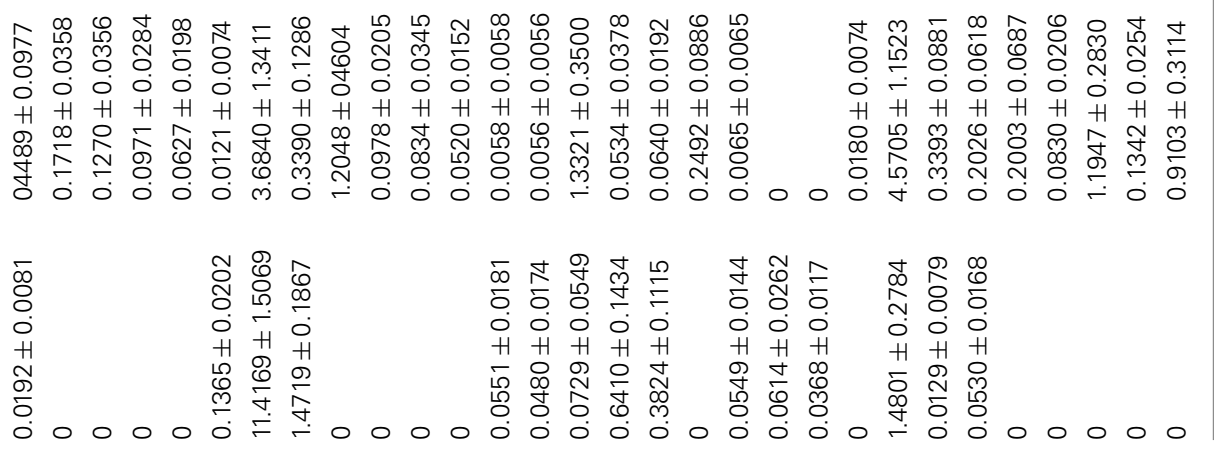

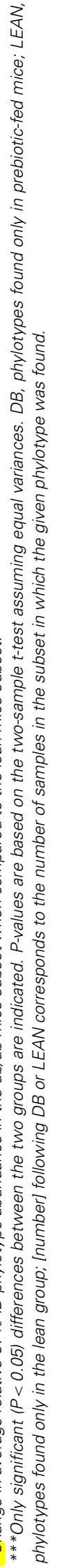

